\title{
Seasonal variation of photosynthetic model parameters and leaf area index from global Fluxnet eddy covariance data
}

\author{
M. Groenendijk, ${ }^{1,2}$ A. J. Dolman, ${ }^{1}$ C. Ammann, ${ }^{3}$ A. Arneth,${ }^{4,5}$ A. Cescatti, ${ }^{6}$ D. Dragoni, ${ }^{7}$ \\ J. H. C. Gash, ${ }^{1}$ D. Gianelle, ${ }^{8}$ B. Gioli, ${ }^{9}$ G. Kiely, ${ }^{10}$ A. Knohl, ${ }^{11}$ B. E. Law, ${ }^{12}$ M. Lund,, 13 \\ B. Marcolla, ${ }^{8}$ M. K. van der Molen, ${ }^{14}$ L. Montagnani, ${ }^{15,16}$ E. Moors, ${ }^{17}$ \\ A. D. Richardson, ${ }^{18}$ O. Roupsard, ${ }^{19,20}$ H. Verbeeck, ${ }^{21}$ and G. Wohlfahrt ${ }^{22}$
}

Received 20 April 2011; revised 28 September 2011; accepted 6 October 2011; published 15 December 2011.

[1] Global vegetation models require the photosynthetic parameters, maximum carboxylation capacity $\left(V_{c m}\right)$, and quantum yield $(\alpha)$ to parameterize their plant functional types (PFTs). The purpose of this work is to determine how much the scaling of the parameters from leaf to ecosystem level through a seasonally varying leaf area index ( $L A I)$ explains the parameter variation within and between PFTs. Using Fluxnet data, we simulate a seasonally variable $L A I_{F}$ for a large range of sites, comparable to the $L A I_{M}$ derived from MODIS. There are discrepancies when $L A I_{F}$ reach zero levels and $L A I_{M}$ still provides a small positive value. We find that temperature is the most common constraint for $L A I_{F}$ in $55 \%$ of the simulations, while global radiation and vapor pressure deficit are the key constraints for $18 \%$ and $27 \%$ of the simulations, respectively, while large differences in this forcing still exist when looking at specific PFTs. Despite these differences, the annual photosynthesis simulations are comparable when using $L A I_{F}$ or $L A I_{M}\left(r^{2}=0.89\right)$. We investigated further the seasonal variation of ecosystem-scale parameters derived with $L A I_{F}$. $V_{c m}$ has the largest seasonal variation. This holds for all vegetation types and climates. The parameter $\alpha$ is less variable. By including ecosystem-scale parameter seasonality we can explain a considerable part of the ecosystem-scale parameter variation between PFTs. The remaining unexplained leaf-scale PFT variation still needs further work, including elucidating the precise role of leaf and soil level nitrogen.

Citation: Groenendijk, M., et al. (2011), Seasonal variation of photosynthetic model parameters and leaf area index from global Fluxnet eddy covariance data, J. Geophys. Res., 116, G04027, doi:10.1029/2011JG001742.

\section{Introduction}

[2] Global land surface schemes represent ecosystem characteristics by model parameters and state variables [e.g.,

\footnotetext{
${ }^{1}$ Department of Hydrology and Geo-Environmental Sciences, Faculty of Earth and Life Sciences, VU University Amsterdam, Amsterdam, Netherlands.

${ }^{2}$ College of Engineering, Mathematics and Physical Sciences, University of Exeter, Exeter, UK.

${ }^{3}$ Federal Research Station Agroscope ART, Zürich, Switzerland.

${ }^{4}$ Department of Earth and Ecosystem Sciences, Division of Physical Geography and Ecosystem Analysis, Lund University, Lund, Sweden.

${ }^{5}$ Karlsruhe Institute of Technology, Institute for Meteorology and Climate Research/Atmospheric Environmental Research, Karlsruhe, Germany.

${ }^{6}$ European Commission, Joint Research Centre, Institute for Environment and Sustainability, Ispra, Italy.

${ }^{7}$ Department of Geography, Indiana University, Bloomington, Indiana, USA.

${ }^{8}$ Sustainable Agro-ecosystems and Bioresources Department, IASMA Research and Innovation Centre, Fondazione Edmund Mach, San Michele all'Adige, Italy.

${ }^{9}$ Institute of Biometeorology, CNR, Firenze, Italy.

Copyright 2011 by the American Geophysical Union. 0148-0227/11/2011JG001742
}

Sellers et al., 1997; Foley et al., 1998; Bonan et al., 2002; Sitch et al., 2003; Krinner et al., 2005]. A key issue for modelers is how to balance the detail required for process-

\footnotetext{
${ }^{10}$ Hydromet Research Group, Civil and Environmental Engineering Department, University College Cork, Cork, Ireland.

${ }^{11}$ Department of Bioclimatology, Büsgen Institute, Georg-August University of Göttingen, Göttingen, Germany.

${ }^{12}$ College of Forestry, Oregon State University, Corvallis, Oregon, USA.

${ }^{13}$ Department of Arctic Environment, National Environmental Research Institute, Aarhus University, Roskilde, Denmark.

${ }^{14}$ Meteorology and Air Quality Group, Wageningen University and Research Centre, Wageningen, Netherlands.

${ }^{15}$ Forest Services and Agency for the Environment, Bolzano, Italy.

${ }^{16}$ Faculty of Science and Technology, Free University of Bolzano Bozen, Bolzano, Italy.

${ }^{17}$ Earth System Science and Climate Change Group, Alterra, Wageningen University and Research Centre, Wageningen, Netherlands.

${ }^{18}$ Department of Organismic and Evolutionary Biology, Harvard University, Cambridge, Massachusetts, USA.

${ }^{19}$ UMR Eco and Sols, French Agricultural Research Centre for International Development, Montpellier, France.

${ }^{20}$ Tropical Agricultural Research and Higher Education Centre, Turrialba, Costa Rica.

${ }^{21}$ Laboratory of Plant Ecology, Ghent University, Ghent, Belgium.

${ }^{22}$ Institut für Ökologie, Universität Innsbruck, Innsbruck, Austria.
} 
Table 1. List of Most Important Parameters Derived for All Sites in Appendix A ${ }^{\mathrm{a}}$

\begin{tabular}{llll}
\hline Parameter & \multicolumn{1}{c}{ Scale } & Data & \multicolumn{1}{c}{ Definition } \\
\hline$V_{c m, F}$ & Ecosystem, seasonal & Fluxnet & Ecosystem carboxylation capacity $\left(\mu \mathrm{mol} \mathrm{m}^{-2} \mathrm{~s}^{-1}\right)$ \\
$v_{c m, 25 F}$ & Leaf, constant & Fluxnet & Leaf carboxylation capacity $\left(\mu \mathrm{mol} \mathrm{m}^{-2} \mathrm{~s}^{-1}\right)$ \\
$V_{c m, M}$ & Ecosystem, seasonal & MODIS & Ecosystem carboxylation capacity $\left(\mu \mathrm{mol} \mathrm{m}^{-2} \mathrm{~s}^{-1}\right)$ \\
$v_{c m, 25 M}$ & Leaf, constant & MODIS & Leaf carboxylation capacity $\left(\mu \mathrm{mol} \mathrm{m}^{-2} \mathrm{~s}^{-1}\right)$ \\
$V_{c m, B}$ & Ecosystem, seasonal & Fluxnet & Bulk carboxylation capacity $\left(\mu \mathrm{mol} \mathrm{m}^{-2} \mathrm{~s}^{-1}\right)$ \\
$\alpha_{e, F}$ & Ecosystem, seasonal & Fluxnet & Ecosystem quantum yield $\left(\mathrm{mol} \mathrm{mol}^{-1}\right)$ \\
$\alpha_{F}$ & Leaf, constant & Fluxnet & Leaf quantum yield $\left(\mathrm{mol} \mathrm{mol}^{-1}\right)$ \\
$\alpha_{e, M}$ & Ecosystem, seasonal & MODIS & Ecosystem quantum yield $\left(\mathrm{mol} \mathrm{mol}^{-1}\right)$ \\
$\alpha_{M}$ & Leaf, constant & MODIS & Leaf quantum yield $\left(\mathrm{mol} \mathrm{mol}^{-1}\right)$ \\
$\alpha_{e, B}$ & Ecosystem, seasonal & Fluxnet & Bulk quantum yield $\left(\mathrm{mol} \mathrm{mol}^{-1}\right)$ \\
\hline
\end{tabular}

a Parameters are derived with Fluxnet or MODIS data and kept constant over time or are seasonally variable.

oriented simulations against the need for generality and the availability of parameters at large spatial and temporal scales. Leaf and canopy processes are well-known, but the level of understanding at the global scale is still inadequate. The pragmatic solution is to apply small-scale knowledge at the larger spatial and temporal scales [Jarvis, 1995].

[3] The process of photosynthesis is central to any land surface scheme that aims to model the global carbon balance. For example, the photosynthesis model of Farquhar et al. [1980] is used in many global models [e.g., Sellers et al., 1997; Knorr, 2000; Arora, 2002; Sitch et al., 2003; Krinner et al., 2005]. Yet, although this model was developed for individual leaves at a temporal scale of several hours, it is applied at larger spatial scales by using leaf area index $(L A I)$ to upscale the leaf-scale maximum carboxylation capacity $\left(v_{c m, 25}\right)$ and quantum yield $(\alpha)$ or the leaf-scale photosynthesis flux. Upscaling assumes a particular radiation distribution within a canopy, in big leaf [Sellers et al., 1992], multilayer [Baldocchi and Harley, 1995], sun/shade [de Pury and Farquhar, 1997], and three-dimensional models [Dauzat et al., 2001]. This is combined with assumptions about the distribution of leaf nitrogen and photosynthetically active radiation $(P A R)$ over the canopy profile [Reich et al., 1997].

[4] Photosynthetic parameters are normally estimated at the leaf scale but can be determined at the ecosystem scale through the inverse application of ecosystem models using eddy-covariance (EC) flux observations. At the leaf scale there is evidence that parameters are seasonally variable and change with leaf age, temperature, water availability, and nitrogen content [e.g. Wilson et al., 2001; Medlyn et al., 2002; Xu and Baldocchi, 2003; Mäkelä et al., 2004; Misson et al., 2006; Kolari et al., 2007; Misson et al., 2010]. At the ecosystem-scale, seasonal variability of $V_{c m}$ and $\alpha_{e}$ (Table 1) derived from EC observations has been observed for a range of sites [Reichstein et al., 2003a; Wang et al., 2003; Owen et al., 2007; Wang et al., 2007; Mo et al., 2008; Thum et al., 2008], but between-site differences could be related to the mean summer LAI [Lindroth et al., 2008].

[5] Photosynthetic parameters in global models are usually defined by plant functional types (PFTs) [Box, 1996; Bonan et al., 2002; Sitch et al., 2003; Krinner et al., 2005]. The variation of leaf-scale $v_{c m, 25}$ between and within PFTs is derived by Kattge et al. [2009] and related to leaf nitrogen content in natural vegetation. This relationship varies by vegetation type, but the relationship with nitrogen-use efficiency is independent of vegetation type. Williams et al. [2009] state that the Fluxnet data could be used to challenge and enrich the PFT approach at the ecosystem scale. A comparison of annual photosynthetic model parameters derived from 101 sites in the global Fluxnet data indicated that the ecosystem parameters are more variable than assumed within the PFTs and that a PFT-based classification does not reflect the reality of short-term photosynthesis and transpiration flux variation [Groenendijk et al., 2011]. Furthermore, Alton [2011] reported that model parameters overlap between PFTs and that modeled carbon fluxes are especially sensitive to the classification of model parameters. These three examples raise issues regarding the classification and distribution of model parameters. This study aims to answer the question: what is the influence of seasonal variability on the ecosystem parameter variation within a PFT? Our hypothesis is that meteorological data can be used to constrain seasonal ecosystem-scale parameter variation.

[6] The overall objective of this study is thus to improve the understanding of the temporal and spatial variation of the photosynthetic model parameters, with an emphasis on their relationship with $L A I$ and meteorological variables. The study aims to expand upon previous work [Groenendijk et al., 2011] by further refining photosynthetic parameters derived from tower flux observations. Specific objectives are: (1) determine if $L A I$ scaling of the parameters results in a better understanding of the parameter variation within and between PFTs; (2) quantify sensitivity of photosynthetic parameters to $L A I$ variations; (3) determine if the Fluxnet $\mathrm{EC}$ and meteorological data can be used to derive a seasonal $L A I$; and (4) if this is comparable to $L A I$ derived from MODIS, which can be used over larger areas.

\section{Methods}

\subsection{Overview}

[7] We use a big leaf model that can be applied at all Fluxnet sites without additional site-specific information on canopy architecture. Ecosystem-scale parameters $\left(V_{c m}\right.$ and $\alpha_{e}$ ) are derived from an integrated light exponential profile, leaf-scale parameters $\left(v_{c m, 25}\right.$ and $\left.\alpha\right)$ and LAI [Field, 1983; Sellers et al., 1992]. Parameter definitions are presented in Table 1 . The leaf-scale model parameters $v_{c m, 25}$ and $\alpha$ are assumed constant in time and scaled with $L A I$ to obtain seasonally variable ecosystem-scale parameters $V_{c m}$ and $\alpha_{e}$. This assumption separates spatial and temporal parameter 

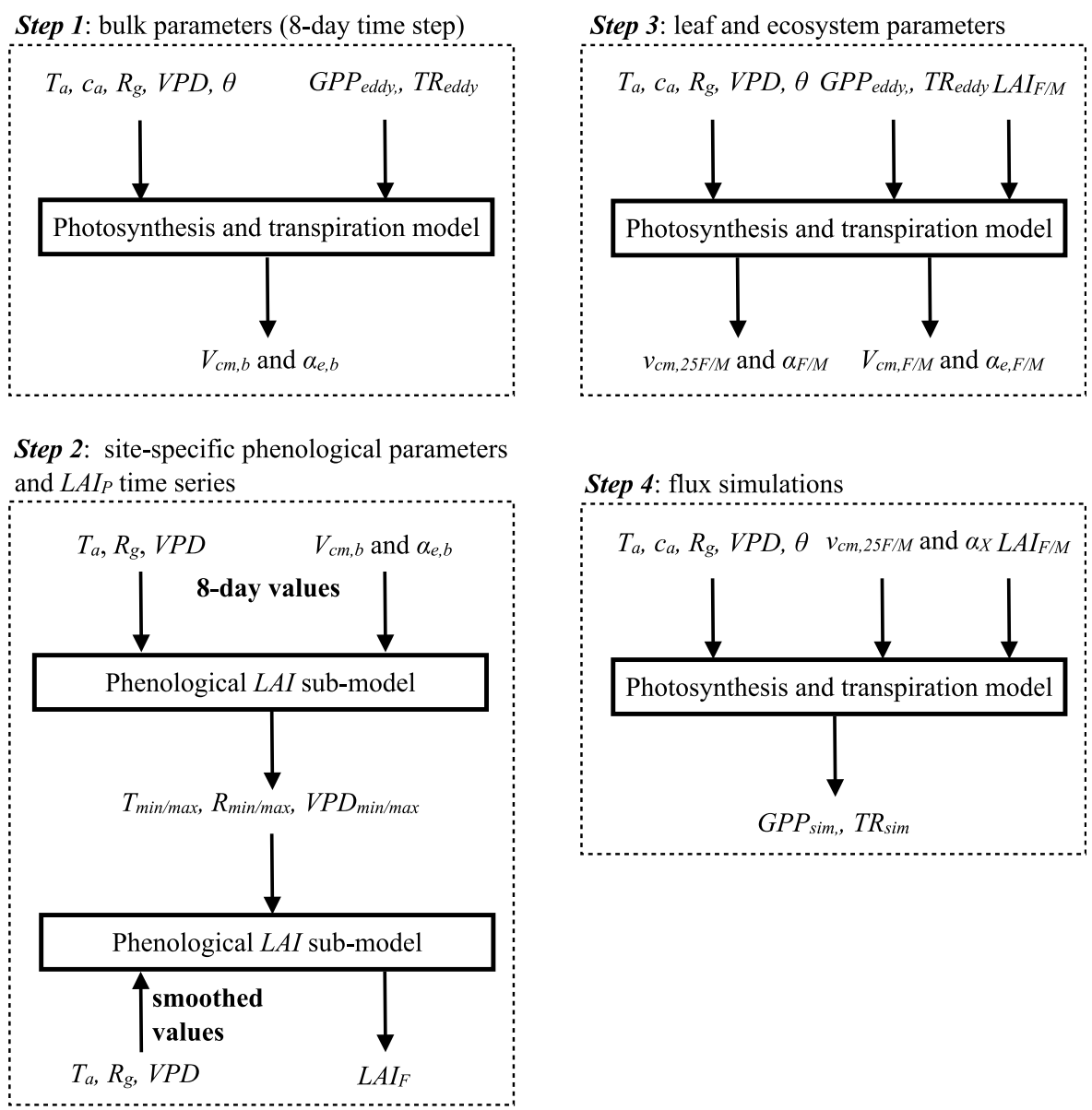

Figure 1. Data flow diagram used to derive leaf-scale $\left(v_{c m, 25 F / M}\right.$ and $\left.\alpha_{F / M}\right)$ and ecosystem-scale parameters $\left(V_{c m, F / M}\right.$ and $\left.\alpha_{e, F / M}\right)$ from observed meteorological data $\left(T_{a}, C_{a}, R_{g}, V P D, \theta\right)$ and flux data $\left(G P P_{e d d y}\right.$, $T R_{\text {eddy }}$ ). In steps 3 and 4 either $L A I_{F}$ (Fluxnet) or $L A I_{M}$ (MODIS) is used.

contributions to the overall variation. To account for seasonal changes in $L A I$ and meteorology, a phenological submodel [Jolly et al., 2005; Stöckli et al., 2008] is used as an alternative to MODIS retrievals of $L A I$ [Distributed Active Archive Center (DAAC), 2009]. This modeling strategy is chosen to produce insights in the climatic constraints on $L A I$ and the influence of $L A I$ on the variation of ecosystem-scale physiological parameters. In addition, it allows examination of the potential for simulating $L A I$ using only meteorological tower observations that are measured at the same spatial scale as the eddy covariance fluxes. The range of parameters (Table 1) provides flexibility identifying relationships at different scales.

[8] We take a four step approach to using global Fluxnet and MODIS observations to quantify the influence of seasonal variation of photosynthetic model parameters on the parameter variation between sites and PFTs. Seasonal LAI is derived from Fluxnet observations (section 2.2) with the models described in sections 2.3 and 2.4. In this second step, seasonally variable bulk parameters $V_{c m, B}$ and $\alpha_{e, B}$ are used from the first step, where $L A I$ scaling is implicitly included. This allows us to derive a seasonal signal from the parameters. Third, $L A I$ derived from both the Fluxnet data $\left(L A I_{F}\right)$ and MODIS data $\left(L A I_{M}\right)$ is used to obtain two sets of leaf-scale photosynthetic parameters $\left(v_{c m, 25 F}, \alpha_{F}\right.$ and $\left.v_{c m, 25 M}, \alpha_{M}\right)$. Finally, in the fourth step, the leaf-scale parameters and $L A I_{F}$ or $L A I_{M}$ are used to simulate the photosynthesis and transpiration fluxes.

\subsection{Observations}

[9] The Fluxnet database contains ecosystem fluxes of carbon, water, and energy measured with the eddy-covariance technique [Aubinet et al., 2000]. All data are processed in a harmonized manner following Baldocchi et al. [2001], Papale and Valentini [2003], Reichstein et al. [2005], Papale et al. [2006], Moffat et al. [2007], and Baldocchi [2008]. The following variables are required to apply the photosynthesis and transpiration model and derive the photosynthetic parameters (Figure 1): net ecosystem exchange (NEE), latent heat flux $(L E)$, air temperature $\left(T_{a}\right)$, global radiation $\left(R_{g}\right)$, vapor pressure deficit $(V P D)$, soil water content $(\theta)$, and maximum leaf area index $\left(L A I_{\max }\right)$. Here $\theta$ is observed in the topsoil at an average depth of $5-15 \mathrm{~cm}$. These point observations are not representative for the full tower footprint, but the temporal dynamics of wetting and drying are. We have excluded sites with data gaps of more than $50 \%$ during the growing season, missing input variables, or having less than 2 years of data. On the basis of these criteria the sites in Appendix A were selected from the Fluxnet database (www.fluxdata. org) of April 2008. 
[10] Within the Fluxnet database, the observed $N E E$ is partitioned into gross primary production $\left(G P P_{e d d y}\right)$ and ecosystem respiration $\left(R_{e}\right) . R_{e}$ is determined from the temperature dependence of nighttime ecosystem fluxes using the methodology of Reichstein et al. [2005] and subtracted from $N E E$ to estimate $G P P_{e d d y}$. $G P P_{e d d y}$ is compared with simulated photosynthesis $\left(G P P_{\text {sim }}\right.$, see next section), but because $G P P_{e d d y}$ is derived from observed $N E E$ and simulated $R_{e}$ there are uncertainties associated with this method that may affect model results [Lasslop et al., 2008; Vickers et al., 2009; Lasslop et al., 2010]. Simulated latent heat fluxes are compared with observations to estimate model parameters, but the observed flux is the sum of transpiration and soil evaporation. We assume that during periods with no precipitation total evaporation equals transpiration $\left(T R_{o b s}\right)$, which includes both the overstorey and understorey. These periods were selected by excluding data for days with precipitation and 3 days thereafter. All models (see Figure 1) are optimized with non-gap-filled observed data only.

[11] $L A I_{M}$ is derived from the MODIS database [DAAC, 2009] for a $7 \times 7 \mathrm{~km}$ area centered on each site. The database contains 8-day composite values of $L A I_{M}$ with no clouds and no presence of snow and ice $(1 \times 1 \mathrm{~km}$ resolution). The average of observations over the $7 \times 7 \mathrm{~km}$ areas is calculated, and the 8-day composites are linearly interpolated and smoothed with a moving average of 24 days to determine half-hourly values.

\subsection{Photosynthesis and Transpiration Model}

[12] The model used in this study is based on the equations of Cowan [1977], Farquhar et al. [1980], and Arneth et al. [2002] and is fully described in the appendix of Groenendijk et al. [2011]. Photosynthesis $\left(G P P_{\text {sim }}\right)$ is given as the minimum of carboxylation $\left(W_{c}\right)$ and Ribulose-1,5bisphosphate $(\mathrm{RuBP})$ regeneration $\left(W_{f}\right)$ minus dark respiration $\left(R_{d}\right)$.

$$
G P P_{\text {sim }}=\beta\left[\left(1-\Gamma^{*} / C_{i}\right) \min \left\{W_{c}, W_{j}\right\}-R_{d}\right]
$$

where $\beta$ is a factor to reduce photosynthesis during dry periods, $\Gamma^{*}$ is the compensation point for $\mathrm{CO}_{2}$ in the absence of dark respiration (ppm), and $C_{i}$ the mole fraction of $\mathrm{CO}_{2}$ (ppm) and $R_{d}=0.07 V_{c m}$. $W_{c}$ is a function of the parameter $V_{c m}$, and $W_{f}$ is a function of the parameters $J_{m}$ and $\alpha$ :

$$
\begin{gathered}
W_{c}=\frac{V_{c m} C_{i}}{C_{i}+k^{\prime}} \\
W_{j}=\frac{J C_{i}}{4\left(C_{i}+2 \Gamma^{*}\right)} \\
k^{\prime}=K_{c}\left(1+O / K_{o}\right) \\
\Gamma^{*}=0.5 \frac{V_{o m}}{V_{c m}} \frac{K_{c}}{K_{o} O} \\
J=\frac{\alpha I_{P A R} J_{m}}{\alpha I_{P A R}+2.1 J_{m}}
\end{gathered}
$$

where $I_{P A R}$ is the absorbed photosynthetically active radiation ( $\mu$ mol photons $\left.\mathrm{m}^{-2} \mathrm{~s}^{-1}\right), J$ is the electron yield, $V_{c m}$ is the rate of carboxylation mediated by the enzyme Rubisco $\left(\mu \mathrm{mol} \mathrm{m} \mathrm{m}^{-2} \mathrm{~s}^{-1}\right), V_{c m}$ is the rate of oxygenation of Rubisco $\left(\mu \mathrm{mol} \mathrm{m} \mathrm{m}^{-2} \mathrm{~s}^{-1}\right), J_{m}$ is the maximum potential electron transport rate $\left(\mu \mathrm{mol} \mathrm{m} \mathrm{m}^{-2} \mathrm{~s}^{-1}\right), \alpha$ is the quantum yield (mol $\left.\mathrm{mol}^{-1}\right), K_{c}$ is the kinetic coefficient for $\mathrm{CO}_{2}$ (bar), $K_{o}$ is the kinetic coefficient for $\mathrm{O}_{2}$ (bar), and $O$ is the partial pressure for $\mathrm{O}_{2}$ (bar). The ratio $V_{c m} / V_{c m}$ is assumed to be a constant value of 0.21 . The quantum yield is an adjustable parameter and contains a constant intrinsic quantum yield and a $P A R$ absorption parameter, which is variable as a result of the optical characteristics of leaves, branches, and canopies. This model is developed for $\mathrm{C}_{3}$ vegetation and therefore can introduce uncertainty to model parameters and fluxes derived for sites where a part of the vegetation is $\mathrm{C}_{4}$. The number of sites containing $\mathrm{C}_{4}$ vegetation is very small.

[13] Assuming an infinite boundary layer conductance, transpiration $\left(T R_{\text {sim }}\right)$ is a function of stomatal conductance $\left(g_{s}\right)$, which can be calculated from $G P P_{s i m}, C_{a}$ and $C_{i}$ :

$$
\begin{gathered}
g_{s}=\frac{G P P_{s i m}}{C_{a}-C_{i}} \\
T R_{\text {sim }}=1.6 D g_{s}
\end{gathered}
$$

where $D$ is the molar vapor gradient between leaf intercellular space and ambient air and 1.6 is the ratio of molecular diffusivity of $\mathrm{H}_{2} \mathrm{O}$ to $\mathrm{CO}_{2}$. The internal pressure of $\mathrm{CO}_{2}\left(C_{i}\right)$ is determined as described by Arneth et al. [2002], who linked the models of Cowan [1977] and Farquhar et al. [1980] using the parameter $\lambda$ (the ratio between $T R$ and $G P P$ as a function of $\left.g_{s}\left(\mathrm{~mol} \mathrm{~mol}^{-1}\right)\right)$.

[14] Ecosystem gross primary production $\left(G P P_{\text {sim }}\right)$ and transpiration $\left(T R_{\text {sim }}\right)$ are calculated from half-hourly meteorological data, leaf area index ( $L A I)$, and model parameters describing the ecosystem characteristics. The main leafscale parameters in this model are $v_{c m, 25}\left(\mu \mathrm{mol} \mathrm{m}^{-2} \mathrm{~s}^{-1}\right)$, the rate of carboxylation mediated by the enzyme Rubisco at $25^{\circ} \mathrm{C}$ and $\alpha\left(\mathrm{mol} \mathrm{mol}^{-1}\right)$, the quantum yield. The parameter $v_{c m, 25}$ is converted to $v_{c m}$ with a short-term temperature response [Knorr and Kattge, 2005; Thum et al., 2008]. $j_{m, 25}$ is related to $v_{c m, 25}$ by a constant ratio [Wullschleger, 1993; Leuning, 2002]. In the work of Groenendijk et al. [2011] we derived $j_{m, 25}=3 v_{c m, 25}$ for the Fluxnet sites. Thus we introduce an additional constraint to the present model.

[15] The photosynthesis model of Farquhar et al. [1980] was originally developed for the leaf scale. To use this model at the ecosystem scale, the parameters or fluxes need to be upscaled. The assumption generally used is that the profile of leaf-nitrogen content per unit of leaf area through the depth of the canopy follows the time-mean profile of radiation intensity [Sellers et al., 1992; Reich et al., 1997; Arora, 2002]. Because the leaf photosynthetic properties are proportional to nitrogen content, they also acclimate to the radiation profile, which we used to derive the ecosystemscale properties by multiplication with the integrated exponential function of LAI [Kull and Jarvis, 1995; Cox et al., 1998; Wolf et al., 2006]. The leaf parameters $v_{c m}$ and $\alpha$ 
are converted to ecosystem parameters $V_{c m}$ and $\alpha_{e}$ by upscaling with $L A I$ :

$$
P=p \times \frac{1-\mathrm{e}^{-k L A I}}{k}
$$

where $P$ is the ecosystem-scale parameter and $p$ is the leafscale parameter. Here $k$ represents the extinction coefficient and is set to 0.5 for all sites, although this can vary with canopy structure, including the effects of foliage clumping [Law and Waring, 1994].

\subsection{Phenological LAI Submodel}

[16] The submodel simulates $L A I_{F}$ with observed eddy covariance and meteorological data. We assume the measured fluxes represent conditions within the MODIS area of $7 \times 7 \mathrm{~km}$. The magnitude and significance of differences in the flux source region and MODIS data are addressed by comparing ecosystem parameters $\left(V_{c m}\right.$ and $\left.\alpha_{e}\right)$ and fluxes (GPP and $T R$ ) obtained using the phenological submodel and Fluxnet data with those obtained using MODIS data. The seasonal dynamics of $L A I_{F}$ is simulated as a function of the growing season index $(G S I)$ and a maximum value (LAI $\left.I_{\max }\right)$ [Jolly et al., 2005; Stöckli et al., 2008]:

$$
L A I_{F}=L A I_{\max } \times G S I
$$

where $L A I_{\max }$ is given for each site in the Fluxnet database (Appendix A). GSI is related to seasonal climatic controls of the phenological processes: the minimum air temperature $\left(T_{a}\right)$, global radiation $\left(R_{g}\right)$, and vapor pressure deficit $(V P D)$. The meteorological parameters $T_{\min }, T_{\max }, R_{\min }, R_{\max }$, $V P D_{\min }$, and $V P D_{\max }$ define how $G S I$ varies between 0 and 1.

$$
\begin{gathered}
G S I=f\left(T_{a}\right) \times f\left(R_{g}\right) \times f(V P D) \\
f\left(T_{a}\right)=\frac{T_{a}-T_{\min }}{T_{\max }-T_{\min }} \\
f\left(R_{g}\right)=\frac{R_{g}-R_{\min }}{R_{\max }-R_{\min }} \\
f(V P D)=1-\frac{V P D-V P D_{\min }}{V P D_{\max }-V P D_{\min }} .
\end{gathered}
$$

\subsection{Model Parameter Estimation}

[17] The photosynthesis and transpiration model and the phenological $L A I$ submodel were used to derive parameters and simulate fluxes for all sites in four steps. The differences between parameters are explained here, in Table 1, and in a data flow diagram (Figure 1). The different steps were required because it was not possible to optimize both models together to derive leaf-scale photosynthetic parameters and seasonally variable $L A I$. When this was tried, no unique parameter values were determined. This is due to equifinality, i.e., the problem that different sets of parameters may fit the data equally well, making it impossible to distinguish the correct values [Medlyn et al., 2005]. By using $L A I_{\max }$ the maximum values of $V_{c m}$ and $\alpha_{e}$ are constrained, but when the seasonal variation simulated with the phenological submodel is also included there would be too many parameters to be determined simultaneously. This reduces the equifinality problem, but it still remains in the relation between $L A I$ and the leaf-scale parameters. Comparable fluxes can be obtained by using a different $L A I$ from Fluxnet or MODIS, which is caused by slightly different optimized leaf-scale parameters.

[18] To evaluate model performance with independent data the models were optimized (all steps in Figure 1) using all the data from all the years except one. This omitted year was then used in a validation to compare simulated fluxes with observed fluxes, using the model parameters from the other calibration years. This procedure was repeated for each site, resulting in a number of parameters equal to the number of data years available for each site.

[19] Observed daytime photosynthesis $\left(G P P_{\text {eddy }}\right)$ and transpiration $\left(T R_{e d d y}\right)$, the meteorological variables $T_{a}, R_{g}$, $V P D$, and $\theta$ are used to derive time series of 8 -day bulk model parameters $V_{c m, B}$ and $\alpha_{e, B}$. The photosynthesis and transpiration model is optimized for 8-day periods (step 1 in Figure 1). This time step length is chosen to allow a direct comparison with simulations using MODIS $L A I_{M}$. A simplex search algorithm [Lagarias et al., 1998] is used to find the minimum of the summed normalized root mean square error $\left(R M S E_{n}\right)$ of half-hourly photosynthesis and transpiration within an 8-day period $(N)$. Equal weight is given to both processes:

$$
\begin{aligned}
R M S E_{n}= & \frac{\sqrt{\left(\sum\left(G P P_{\text {sim }}-G P P_{\text {eddy }}\right)^{2}\right) / N}}{\overline{G P P_{\text {eddy }}}} \\
& +\frac{\sqrt{\left(\sum\left(T R_{\text {sim }}-T R_{\text {eddy }}\right)^{2}\right) / N}}{\overline{T R_{\text {edd }}}}
\end{aligned}
$$

[20] With the 8-day bulk parameters $V_{c m, B}$ and $\alpha_{e, B}$ the phenological submodel is parameterized with average 8-day meteorological variables in step 2. The bulk parameters are normalized between 0 and 1 and simultaneously used to derive the phenological model parameters $\left(T_{\min }, T_{\max }, R_{\min }\right.$, $R_{\max }, V P D_{\min }$, and $\left.V P D_{\max }\right)$. The seasonality of the normalized bulk parameters is assumed to be equal to GSI. The minimum $R M S E_{n}$ is searched for:

$$
R M S E_{n}=\frac{\sqrt{\left(\sum\left(G S I_{\text {sim }}-G S I_{\text {pars }}\right)^{2}\right) / N}}{\overline{G S I_{\text {pars }}}}
$$

where $G S I_{\text {sim }}$ is simulated growing season index (equation (11)) and $G S I_{\text {pars }}$ normalized bulk parameters. To obtain a smooth time series, $L A I_{F}$ is simulated with the phenological parameters and meteorological variables smoothed with a moving average of 21 days. This procedure is similar to the use of a moving average in the original phenology model [Jolly et al., 2005].

[21] In step 3 observed daytime photosynthesis $\left(G P P_{e d d y}\right)$ and transpiration $\left(T R_{e d d y}\right)$ fluxes, meteorological variables, and $L A I$ are used to derive the leaf-scale parameters $\left(v_{c m, 25}\right.$ and $\alpha$ ). As in step 1, a simplex search algorithm is used to minimize the difference between the observed and simulated 
a) $\mathrm{CA}-\mathrm{Obs}$

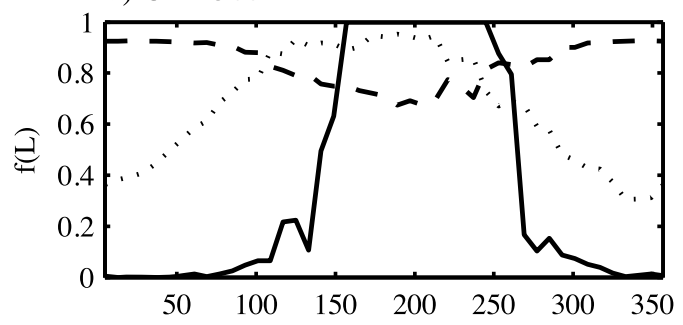

c) US-WCr

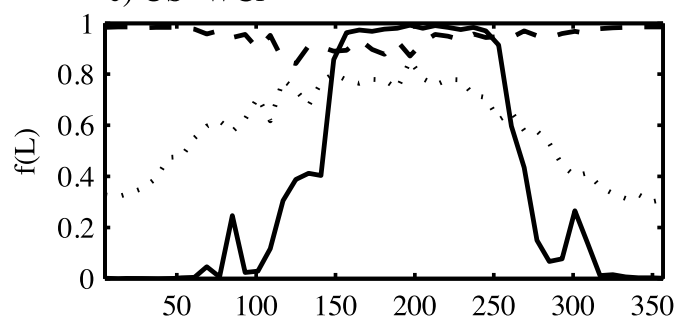

e) $\mathrm{CH}-\mathrm{Oe} 1$

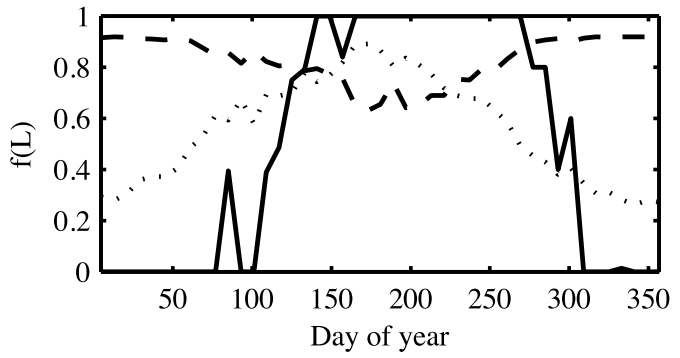

b) ES-ES1

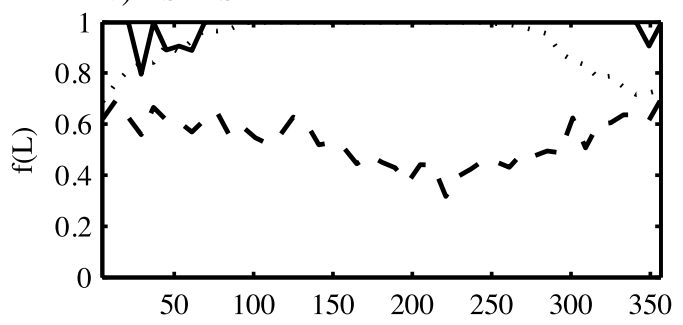

d) IT-Col

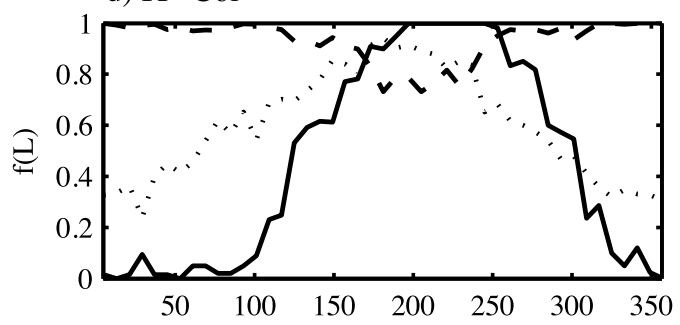

f) US-Goo

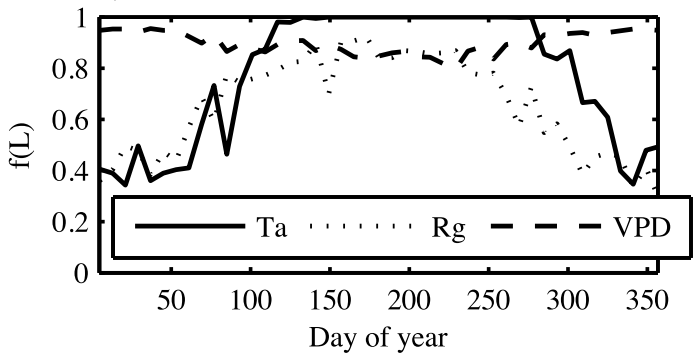

Figure 2. Examples of the seasonal variation of the limiting factors determining the growing season index $\left(G S I_{\text {pars }}\right)$ for six sites derived from the bulk parameters. The limiting factors $\mathrm{f}(L)$ (dimensionless) are air temperature $\left(T_{a}\right)$, global radiation $\left(R_{g}\right)$, and vapor pressure deficit $(V P D)$. For each site the average seasonality of all simulations is shown.

photosynthesis and transpiration. For this step, we use all years of data from each site. Two sets of parameters are derived, using either $L A I_{M}$ (MODIS) or $L A I_{F}$ (Fluxnet). For nine sites the derived site-specific parameters were outside the specified realistic range of 0 to 500 for $v_{c m, 25}$ and 0 to 1 for $\alpha$ (Appendix A). These sites were excluded and all analyses were performed with the remaining 81 Fluxnet sites.

[22] Finally, half-hourly $G P P_{\text {sim }}$ and $T R_{\text {sim }}$ fluxes are simulated in step 4 with the previously estimated parameters and $L A I$. Two sets of fluxes are simulated, using MODIS $L A I_{M}$, or Fluxnet $L A I_{F}$ derived from tower meteorological and flux data.

\section{Results}

\subsection{Phenological LAI Submodel}

[23] Examples of the seasonal control of the meteorological variables on the growing season index $\left(G S I_{\text {pars }}\right)$ for six sites are presented in Figure 2. The sites are selected to represent a large range of vegetation types and climate. The average seasonality of all simulations is shown for each site. CA-Obs and ES-ES1 are evergreen needleleaf forest sites (ENF) with a boreal and Mediterranean climate, respectively; US-WCr and IT-Col are deciduous broadleaf forest sites (DBF) with a temperate-continental and Mediterranean climate; $\mathrm{CH}-\mathrm{Oe} 1$ and US-Goo are grassland sites (GRA) with a temperate and subtropical climate. There are general patterns visible at almost all sites in Figure 2. The start and end of the growing season is controlled by air temperature $\left(T_{a}\right)$, with the shortest growing season at the coldest site (CA-Obs). The end of the growing season is initiated by a decreasing amount of global radiation $\left(R_{g}\right)$. In the middle of the growing season $G S I_{\text {pars }}$ is constrained by vapor pressure deficit (VPD). For the Mediterranean ENF site ES-ES1 there is no clear seasonality, and $G S I_{\text {pars }}$ is only constrained by $V P D$.

[24] $L A I_{F}$ is derived from the curves in Figure 2 by multiplication with $L A I_{\max }$ (equations (10) and (11)). $L A I_{F}$ is compared with $L A I_{M}$ in Figure $3 . L A I_{F}$ is presented as an average seasonality of all simulations for a site. For the ES-ES1 site there is no large seasonal variation in $L A I_{M}$, although the variation is opposite to $L A I_{F}$. The five other sites show a seasonal $L A I_{F}$ that is comparable to $L A I_{M}$ during the growing season, but $L A I_{F}$ is zero during winter and $L A I_{M}$ is not. This is a result of the use of flux data to parameterize the phenological model. When there is no photosynthesis the bulk parameters are zero, even though there is still vegetation present, as is observed with $L A I_{M}$. For the IT-Col site the seasonal $L A I$ observed in the field follows $L A I_{F}$ and not $L A I_{M}$ (L. Montagnani, personal communication, 2011). The fact that $L A I_{M}$ is not zero during winter is an artifact 
a) $\mathrm{CA}-\mathrm{Obs}$

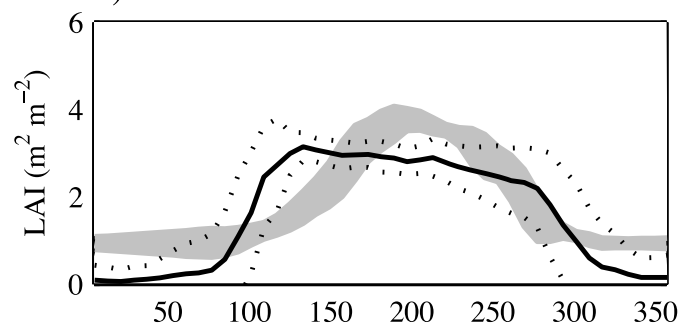

c) US-WCr

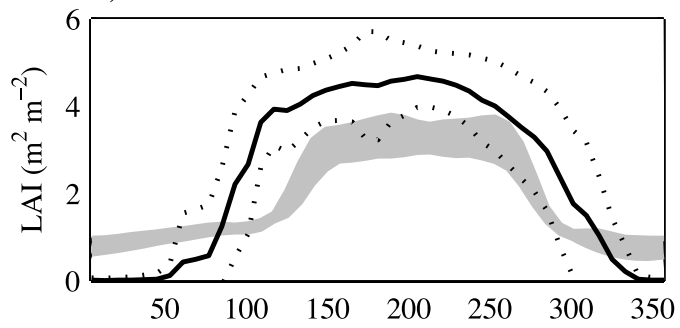

e) $\mathrm{CH}-\mathrm{Oe} 1$

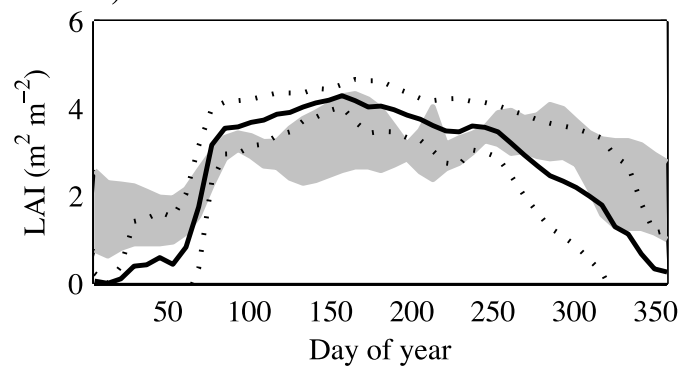

b) ES-ES1

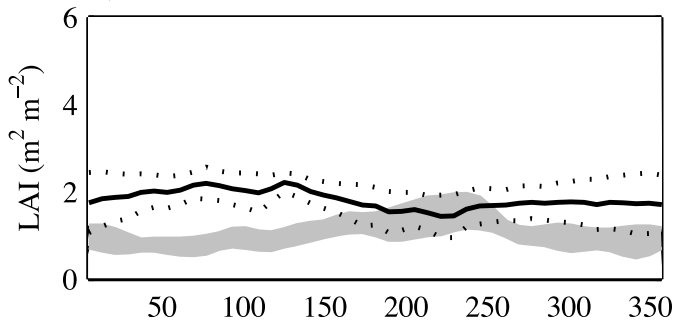

d) IT-Col

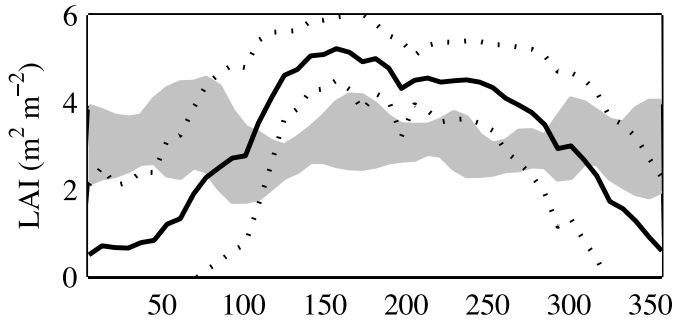

f) US-Goo

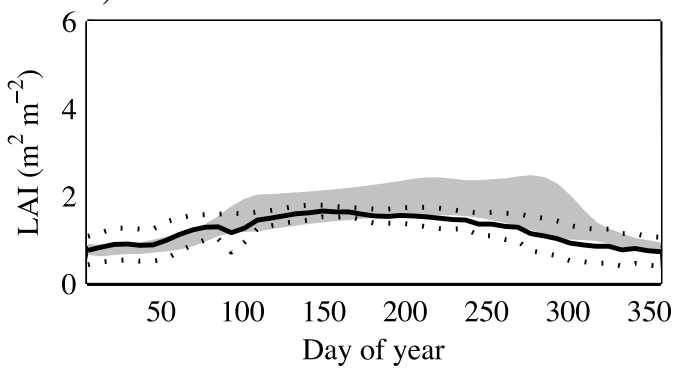

Figure 3. Examples of the average seasonal variation of $L A I_{F}$ (black lines) and $L A I_{M}$ (grey) for six sites. Interannual variation of all simulations for a site is presented with the dashed lines for $L A I_{F}$ and with the grey areas for $L A I_{M}$.

of the MODIS algorithm and of the possibly heterogeneous footprint. At most sites $L A I_{M}$ is a good estimate at the ecosystem scale.

[25] The key meteorological constraint on $G S I_{\text {pars }}$ for each site is determined from the time series of $\mathrm{f}(L)$ as presented in Figure 2. For CA-Obs, $T_{a}$ represents the key constraint for $67 \%$ of the time, $R_{g}$ for $11 \%$, and $V P D$ for $22 \%$. Thus $T_{a}$ is the key meteorological constraint at this site. At US-WCr, IT-Col, and $\mathrm{CH}-\mathrm{Oe} 1 T_{a}$ is also the key constraint with $58 \%$, $54 \%$, and $50 \%$, respectively. At ES-ES1 and US-Goo sites, $V P D$ is the primary constraint with $99 \%$ and $62 \%$, respectively. All simulations (equal to the number of site years) are classified based on these three key meteorological constraints, as summarized in Table 2. The most common constraint is $T_{a}$ for $55 \%$ of the simulations, while $R_{g}$ and $V P D$ are the key constraints for $18 \%$ and $27 \%$ of the simulations, respectively.

\subsection{Seasonal Model Parameter Variation}

[26] Phase and amplitude of the scaled parameters critically depend on the $L A I$ values used in the inversion. Figure 4 thus compares the average difference between $L A I_{M}$ and $L A I_{F}$ for the different vegetation types. For GRA, DBF and ENF sites, $L A I_{F}$ tends to be smaller than $L A I_{M}$ between late fall and late winter, during spring $L A I_{F}$ is larger. For SAV sites $L A I_{F}$ is smaller than $L A I_{M}$ and has an irregular pattern. For EBF sites $L A I_{F}$ is larger than $L A I_{M}$ for most of the year except summer.

[27] Seasonal variation of model parameters is presented for the ecosystem parameters derived using $L A I_{F}$ (Figure 5). For five vegetation types the average seasonal parameter variation is determined by grouping sites with a similar climate (cold, temperate, or warm). The ecosystem parameters derived using $L A I_{M}$ are not shown because the patterns are comparable to those derived with $L A I_{F}$, despite the differences between $L A I_{M}$ and $L A I_{F}$ (Figure 4). Comparison of Figure 5 shows that the largest variation is observed for

Table 2. Distribution of Key Meteorological Constraints of $L A I_{F}$ Over Climate Classes ${ }^{\mathrm{a}}$

\begin{tabular}{lcccc}
\hline \multicolumn{1}{c}{ Climate } & $n_{F}$ & $T_{a}$ & $R_{g}$ & $V P D$ \\
\hline Arctic & 3 & $3(100)$ & - & - \\
Boreal & 83 & $80(96.4)$ & $3(3.6)$ & - \\
Temperate continental & 101 & $45(44.6)$ & $10(9.9)$ & $46(45.5)$ \\
Temperate & 153 & $54(35.3)$ & $47(30.7)$ & $52(34.0)$ \\
Subtropical and Mediterranean & 31 & $27(87.1)$ & $4(12.9)$ & - \\
Tropical & 14 & $2(14.3)$ & $4(28.6)$ & $8(57.1)$ \\
All sites & 385 & $211(54.8)$ & $68(17.7)$ & $106(27.5)$
\end{tabular}

${ }^{\mathrm{a}}$ For each key meteorological constraint (air temperature $\left(T_{a}\right)$, global radiation $\left(R_{g}\right)$, or vapor pressure deficit $\left.(V P D)\right)$ the number of simulations (with percentages between brackets) is presented. $n_{F}$ is the number of simulations for each class. 
a) Grassland

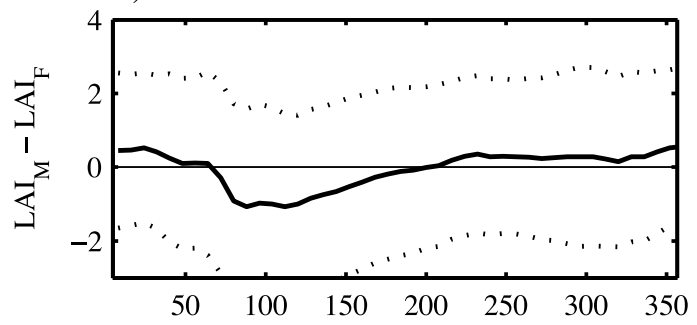

c) Deciduous broadleaf forest

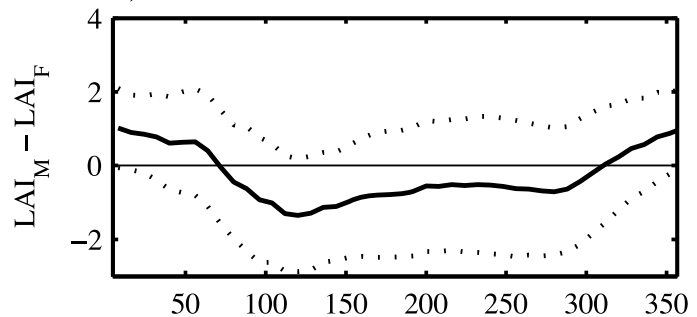

e) Evergreen needleleaf forest

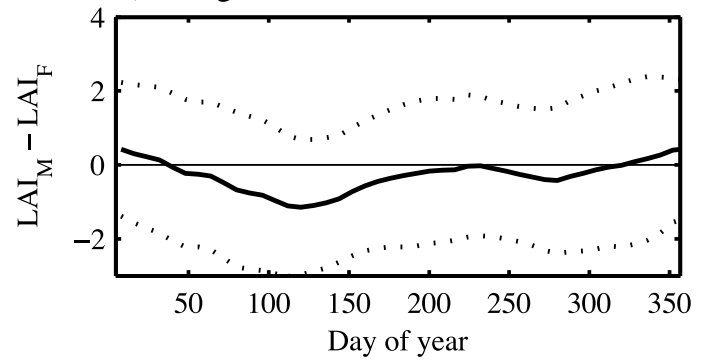

b) Savanna

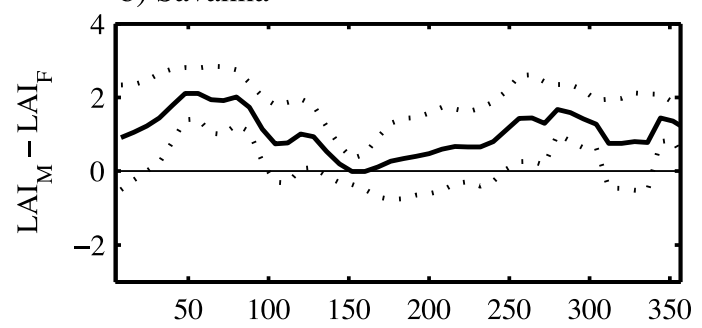

d) Evergreen broadleaf forest

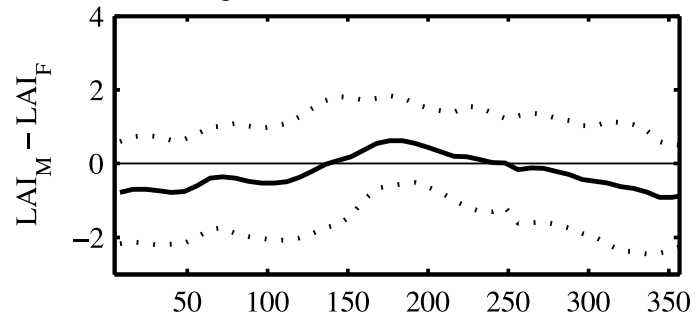

f) All sites

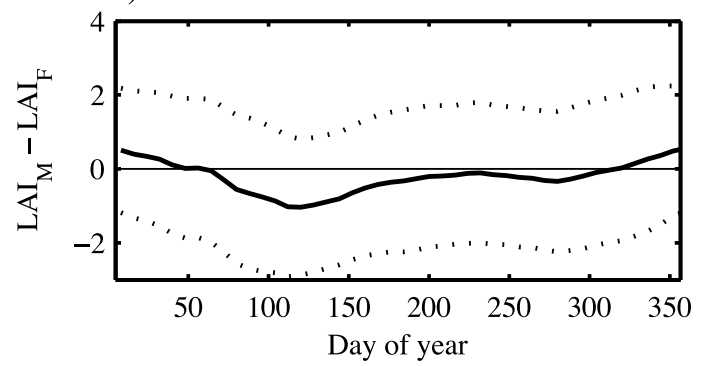

Figure 4. Seasonal variation of the difference between $L A I_{M}$ and $L A I_{F}$ for groups of sites with similar vegetation type and for all sites together. The black line is the average of all simulations and the dotted lines are representing the standard deviation. Sites from the Southern Hemisphere are excluded.

$V_{c m, F}$, for all vegetation types and climates. The parameter $\alpha_{e, P}$ is less variable throughout the year and is even nearly constant for the warm sites. This could be a result of the scaling functions used. $V_{c m, F}$ is a function of $L A I_{F}$ and $T_{a}$, while $\alpha_{e, F}$ is only a function of $L A I_{F}$. A general trend is that the maximum value of $V_{c m, F}$ is largest for the warm sites for all vegetation types. When meteorological key constraints (as in Table 2) are used instead of climate, the differences between the lines is much smaller (not shown). This indicates that although the constraints are able to predict the seasonality of a single site, the difference between sites is more complex and strongly influenced by both vegetation type and climate.

[28] The bulk parameters $\left(V_{c m, B}\right.$ and $\left.\alpha_{e, B}\right)$ derived for the estimation of $G S I_{\text {pars }}$ can be used to evaluate seasonality of the ecosystem parameters $V_{c m, F}$ and $\alpha_{e, F}$. The average difference between bulk and ecosystem parameters for the vegetation types is shown in Figure 6. They are both derived from the same data, but with a different model setup. Differences are a result of the scaling with $L A I$, which is implicitly present in the bulk parameters, and part of the model setup for the ecosystem parameters. Ideally, the two model setups should result in identical model variations. $V_{c m, F}$ of GRA sites is lower than $V_{c m, B}$ during winter and higher during summer. This behavior is related to management, which is not included in the phenology submodel. The bulk parameters are directly derived from flux observations and therefore are affected by management. For the DBF sites, differences show no clear seasonal cycle, lower values of $V_{c m, F}$, and more variability. The difference between $\alpha_{e, F}$ and $\alpha_{e, B}$ of the DBF sites shows a clear seasonal pattern, with the largest deviations in spring. For EBF and ENF sites seasonal variation is similar but less pronounced. The seasonal variation of the difference for EBF sites is almost the opposite, with too low values of $V_{c m, F}$ in spring. $V_{c m, F}$ of ENF sites is lower than $V_{c m, B}$ during the whole season.

\subsection{Spatial Model Parameter Variation}

[29] Spatial variation is quantified by comparing the leafscale model parameters $v_{c m, 25}$ and $\alpha$ for all sites. The parameters were related to average summertime meteorological variables and $L A I$ (not shown), but a relation or dependence was not found for any vegetation type, PFT, or key constraint. There was no direct relation between the meteorological variables and the parameters. Additional variables (e.g., nitrogen content and management history) are required to explain the observed spatial variation.

[30] The site-specific parameters are grouped by vegetation type and climate in Table 3 . The parameters derived from $L A I_{M}$ and $L A I_{F}$ are within the same range, even though they were from independent data sets (only the parameters derived with $L A I_{F}$ are presented in Table 3). It is interesting 


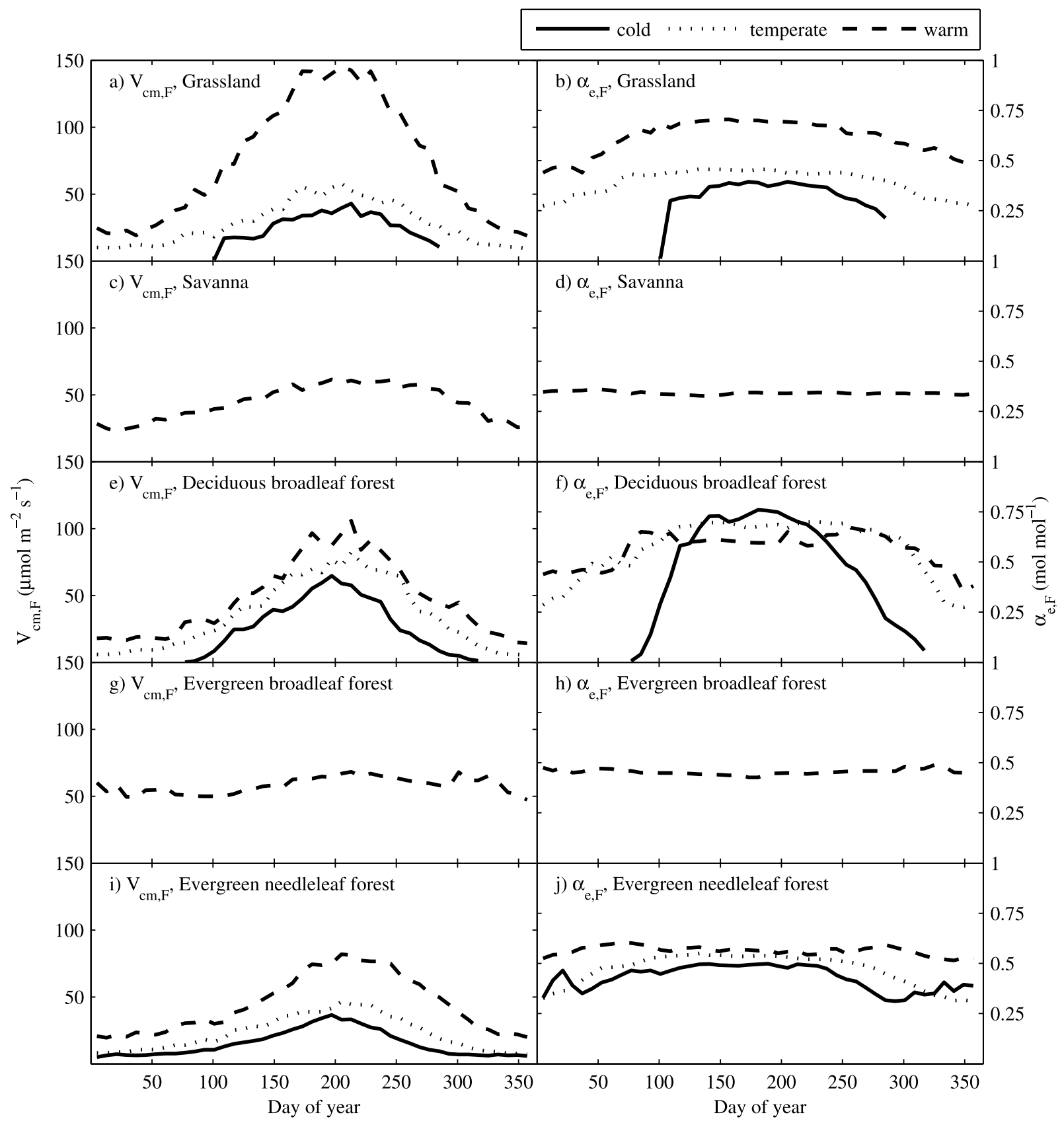

Figure 5. Average seasonal ecosystem parameter variation $\left(V_{c m, F}\right.$ and $\left.\alpha_{e, F}\right)$ for groups of simulations with a similar vegetation type and climate. Sites from the Southern Hemisphere are excluded.

to note that with two independent $L A I$ data sets (MODIS and Fluxnet) comparable parameters were derived. The values for $v_{c m, 25 M}$ and $\alpha_{M}$ are only slightly higher than the values of $v_{c m, 25}$ and $\alpha_{F}$.

[31] Parameters in Table 3 are only of practical use when the differences between the groups are understood. These differences can be explained with the meteorological variables air temperature $\left(T_{a}\right)$ and annual precipitation (Prec) which influence the occurrence of PFTs in many global land-surface schemes [e.g., Bonan et al., 2003; Sitch et al., 2003]. Global radiation $\left(R_{g}\right)$ is added as it is one of the meteorological constraints in the $L A I$ submodel. An average annual $V P D$ is meaningless and therefore not presented.
Lowest values of $v_{c m, 25 F}$ are seen at SAV, warm EBF, and cold and temperate ENF sites, while the highest values of $v_{c m, 25 F}$ are seen at the cropland, cold DBF, temperate EBF, and GRA sites. It is difficult to see any patterns in this variation; for instance, high values at cold sites are difficult to interpret as $25^{\circ} \mathrm{C}$ might not often be reached at these sites. Although one may expect that sites with a low $R_{g}$ have a high $\alpha_{F}$, this is not the case. However, these sites do have higher values for $L A I_{\max , F}$. From this table it can be concluded that the variation of the leaf-scale parameters $v_{c m, 25 F}$ and $\alpha_{F}$ of the different sites have a more complex relationship with the average meteorological variables than the 


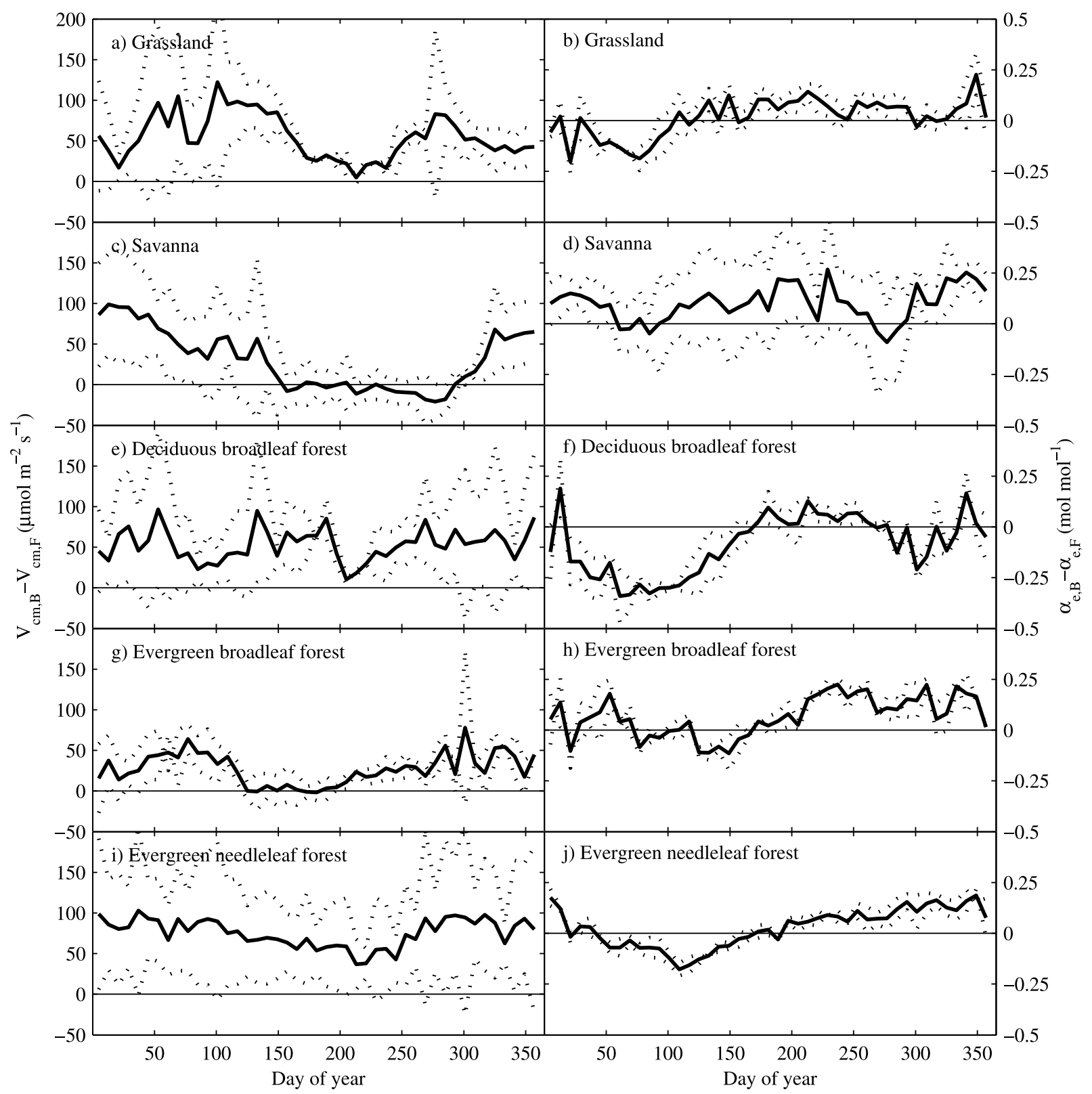

Figure 6. Residual parameter variation not explained by $L A I$ scaling. Average seasonal bulk parameters $\left(V_{c m, B}\right.$ and $\left.\alpha_{e, B}\right)$ minus ecosystem parameters $\left(V_{c m, F}\right.$ and $\left.\alpha_{e, F}\right)$ for groups of sites with a similar vegetation type. The average seasonal residual is presented with the black line and the standard deviation by the dotted lines. Sites from the Southern Hemisphere are excluded.

seasonal variation of the ecosystem-scale parameters in Figure 5 .

\subsection{Flux Simulations}

[32] For validation the half-hourly fluxes were simulated with meteorological variables, $L A I$, and leaf-scale parameters $v_{c m, 25}$ and $\alpha$ (step 4 in Figure 1). The annual photosynthesis $\left(G P P_{\text {sim }}\right)$ and transpiration $\left(T R_{\text {sim }}\right)$ fluxes derived with $L A I_{M}$ and $L A I_{F}$ are compared with observations and each other in Figure 7. The parameters and $L A I$ were derived for different site years than the site year used to validate the fluxes. As expected from the similar seasonal variation of the scaled parameters, the simulated annual photosynthesis fluxes are comparable, with an $r^{2}$ of 0.89
(Figure 7c), and transpiration fluxes are correlated with an $r^{2}$ of 0.91 (Figure 7f). Average photosynthesis and transpiration fluxes are equally simulated with $L A I_{M}$ and $L A I_{F}$. There is variation in the results of the simulated annual fluxes for different vegetation types. Simulated annual photosynthesis of the ENF sites had the strongest correlation, with $r^{2}=$ $0.50-0.64$, but annual transpiration was poorly simulated with $r^{2}=0.28-0.32$ (slope 1.11-1.18 for photosynthesis and $0.69-0.70$ for transpiration). Annual transpiration fluxes of EBF sites were simulated better than for ENF sites $\left(r^{2}=\right.$ $0.44-0.43$, with slopes of 1.23-1.26); however, photosynthesis was simulated poorly $\left(r^{2}=0.27-0.29\right.$ and slopes of $0.90-0.91)$. Both photosynthesis and transpiration fluxes were poorly simulated at GRA and DBF sites. This is a 
Table 3. Average and Standard Deviations of the Leaf-Scale Model Parameters $v_{c m, 25 F}$ and $\alpha_{F}$, Maximum $L A I$, Air Temperature, Global Radiation, and Precipitation Derived With Fluxnet Data for Groups of Simulations With a Similar Vegetation Type and Climate ${ }^{\mathrm{a}}$

\begin{tabular}{|c|c|c|c|c|c|c|c|c|}
\hline Vegetation & Climate & $n_{F}$ & $v_{c m, 25 F}$ & $\alpha_{F}$ & $L A I_{\max , F}$ & $T_{a}$ & $R_{g}$ & Prec \\
\hline \multirow[t]{2}{*}{ Cropland } & temperate & 6 & $105.2(25.9)$ & $0.36(0.13)$ & $7.1(2.8)$ & $9.5(6.2)$ & $123(77)$ & $531(170)$ \\
\hline & warm & 6 & $66.6(11.0)$ & $0.33(0.06)$ & $4.4(1.6)$ & $17.4(5.8)$ & $186(82)$ & 929 (403) \\
\hline \multirow[t]{2}{*}{ Savanna } & cold & 5 & $13.1(1.8)$ & $0.13(0.02)$ & $2.8(0.5)$ & $-0.6(14.9)$ & $131(85)$ & $208(0)$ \\
\hline & warm & 14 & $44.6(8.1)$ & $0.29(0.15)$ & $3.0(1.1)$ & $21.4(5.9)$ & $200(67)$ & $1374(449)$ \\
\hline Deciduous & cold & 7 & 95.9 (12.9) & $0.68(0.11)$ & $2.1(0.1)$ & $1.8(11.9)$ & $132(83)$ & 409 (61) \\
\hline \multirow[t]{2}{*}{ broadleaf forest } & temperate & 35 & $62.0(20.7)$ & $0.50(0.19)$ & $5.0(0.9)$ & $9.3(8.3)$ & $128(81)$ & 773 (151) \\
\hline & warm & 25 & $66.0(24.8)$ & $0.46(0.11)$ & $5.1(1.6)$ & $12.3(8.2)$ & $165(81)$ & 821 (127) \\
\hline Evergreen & temperate & 3 & $86.0(33.8)$ & $0.56(0.32)$ & $5.5(0.0)$ & $13.1(4.6)$ & $158(64)$ & $526(0)$ \\
\hline broadleaf forest & warm & 23 & 39.7 (11.7) & $0.29(0.10)$ & $4.5(1.1)$ & $20.9(6.7)$ & $183(67)$ & $1380(852)$ \\
\hline Evergreen & cold & 71 & $40.6(21.8)$ & $0.32(0.14)$ & $3.7(2.1)$ & $1.5(12.0)$ & $126(83)$ & 443 (192) \\
\hline \multirow[t]{2}{*}{ needleleaf forest } & temperate & 86 & $43.8(10.3)$ & $0.32(0.12)$ & $5.3(2.3)$ & $8.7(7.0)$ & $131(83)$ & 879 (294) \\
\hline & warm & 39 & $72.4(68.1)$ & $0.45(0.17)$ & $4.8(2.4)$ & $13.0(7.5)$ & $167(85)$ & $962(512)$ \\
\hline \multirow[t]{3}{*}{ Grassland } & cold & 3 & $141.6(11.7)$ & $0.56(0.17)$ & $1.1(0.1)$ & $-0.5(8.8)$ & $200(53)$ & $579(0)$ \\
\hline & temperate & 39 & $57.4(25.8)$ & $0.29(0.14)$ & $4.9(2.7)$ & $8.2(7.1)$ & $138(80)$ & 979 (237) \\
\hline & warm & 9 & $103.2(18.2)$ & $0.60(0.11)$ & $2.2(0.3)$ & $13.6(8.4)$ & $166(78)$ & $1181(390)$ \\
\hline \multirow[t]{2}{*}{ Mixed forest } & temperate & 19 & $41.8(19.5)$ & $0.37(0.20)$ & 6.4 (1.6) & $7.1(8.3)$ & $126(74)$ & $774(292)$ \\
\hline & warm & 8 & $40.8(5.1)$ & $0.31(0.04)$ & $5.8(0.9)$ & $15.0(7.8)$ & $148(56)$ & $1072(15)$ \\
\hline
\end{tabular}

${ }^{\mathrm{a}}$ Units of measure are as follows: $v_{c m, 25 F}\left(\mu \mathrm{mol} \mathrm{m}^{-2} \mathrm{~s}^{-1}\right), \alpha_{F}\left(\mathrm{~mol} \mathrm{~mol}^{-1}\right)$, maximum $L A I\left(\mathrm{~m}^{2} \mathrm{~m}^{-2}\right)$, air temperature $\left(T_{a},{ }^{\circ} \mathrm{C}\right)$, global radiation $\left(R_{g}, \mathrm{~W} \mathrm{~m}{ }^{-2}\right)$, and precipitation (Prec, $\mathrm{mm} \mathrm{yr}^{-1}$ ). Here $n_{F}$ is number of simulations with a similar vegetation type and climate.

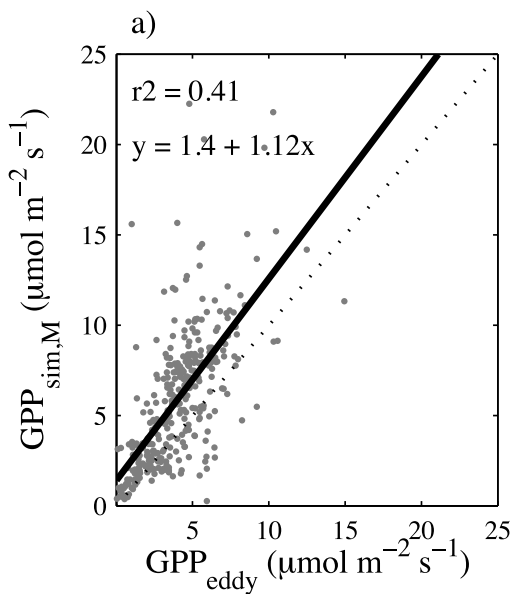

d)

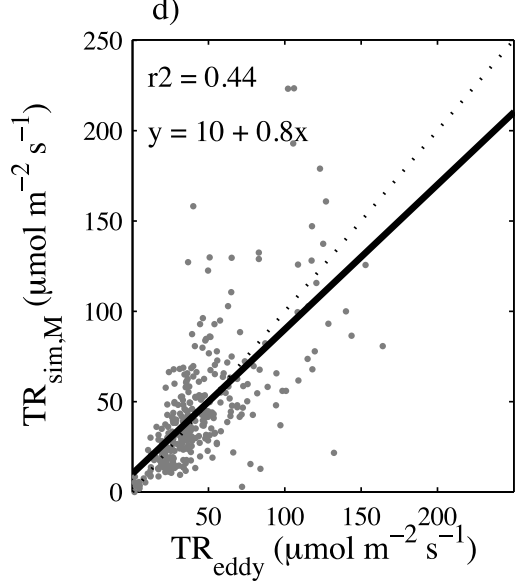

b)

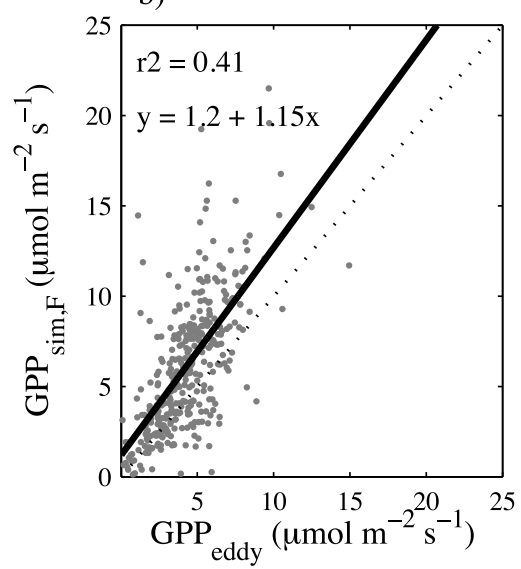

e)

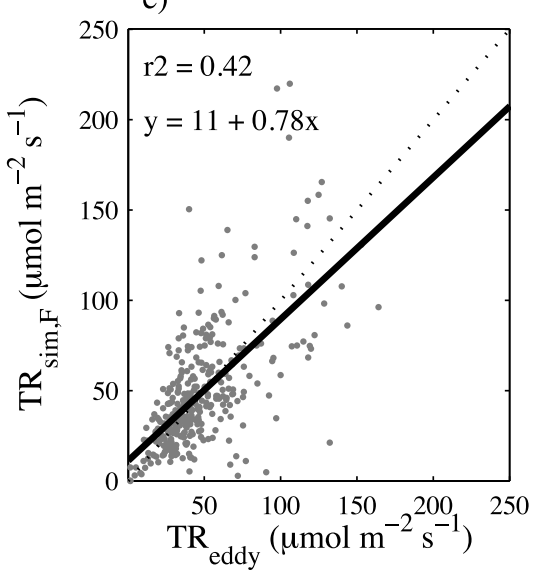

c)
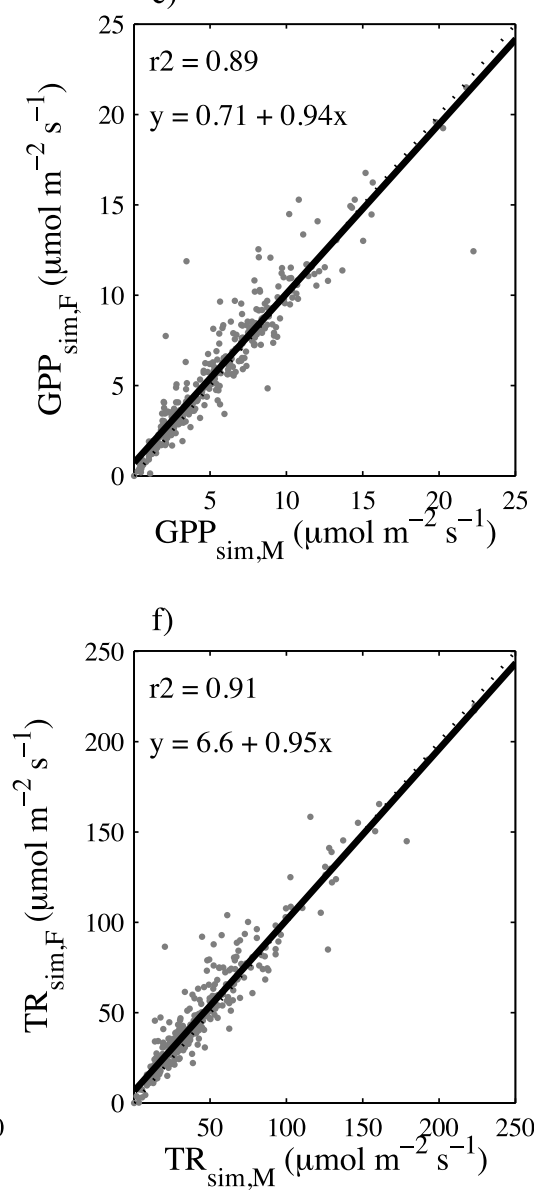

Figure 7. Comparison of observed and simulated annual photosynthesis $(G P P)$ and transpiration $(T R)$ fluxes for all Fluxnet sites used in this study. The simulations are performed with a model using (a, d) MODIS data or (b, e) Fluxnet data. (c, f) The simulated fluxes from the two data sets are compared. Only fluxes observed during dry periods (more than three days after rainfall) were used to ensure a valid comparison. The dashed line is the 1:1 line and the solid line the regression line. 
a) half-hourly GPP

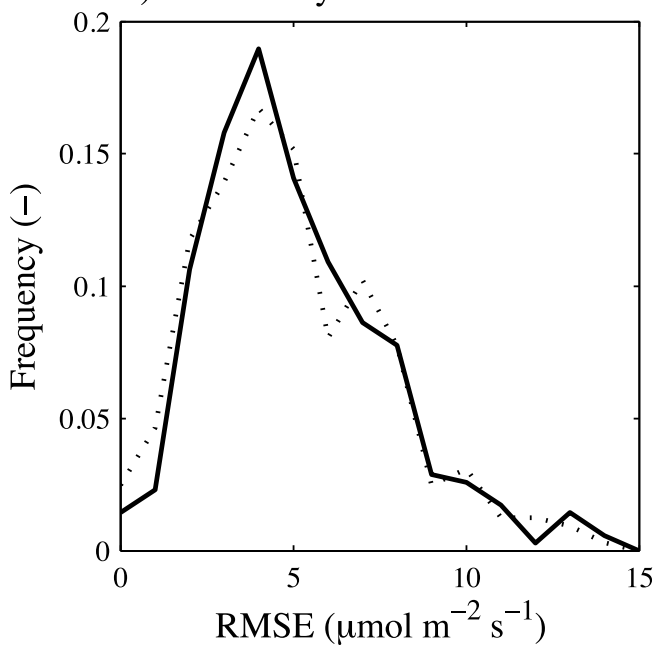

c) 8-daily GPP

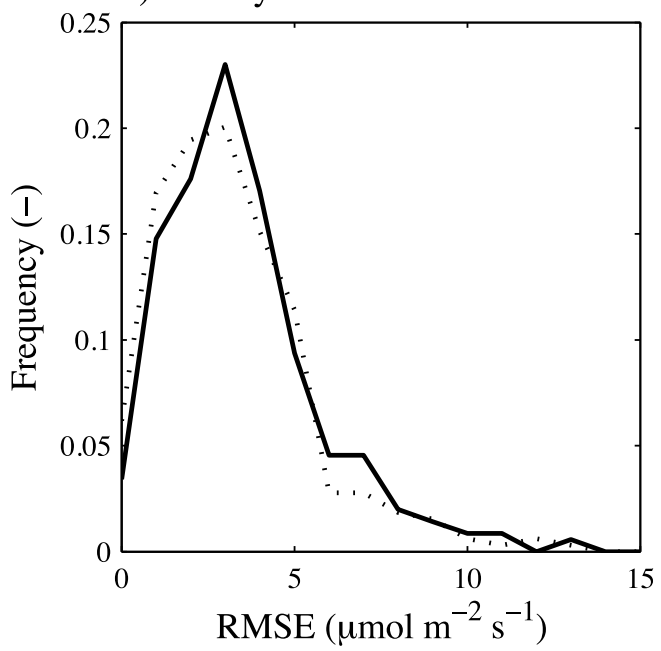

b) half-hourly TR

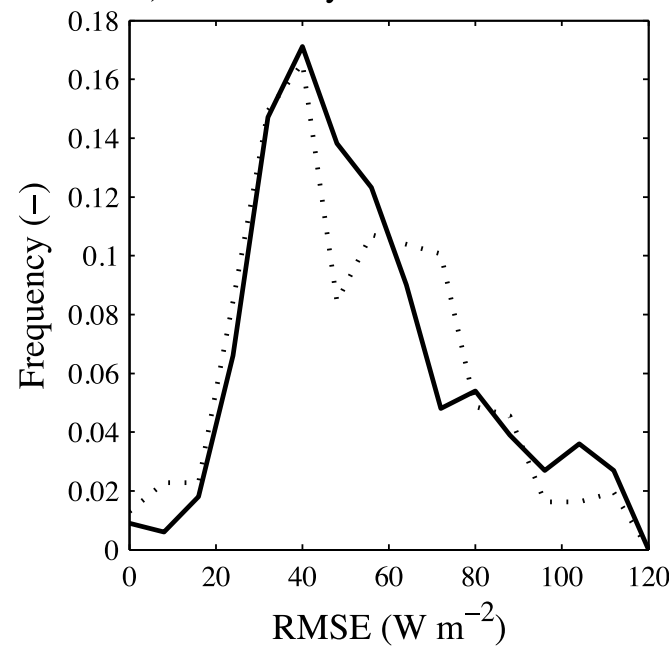

d) 8-daily TR

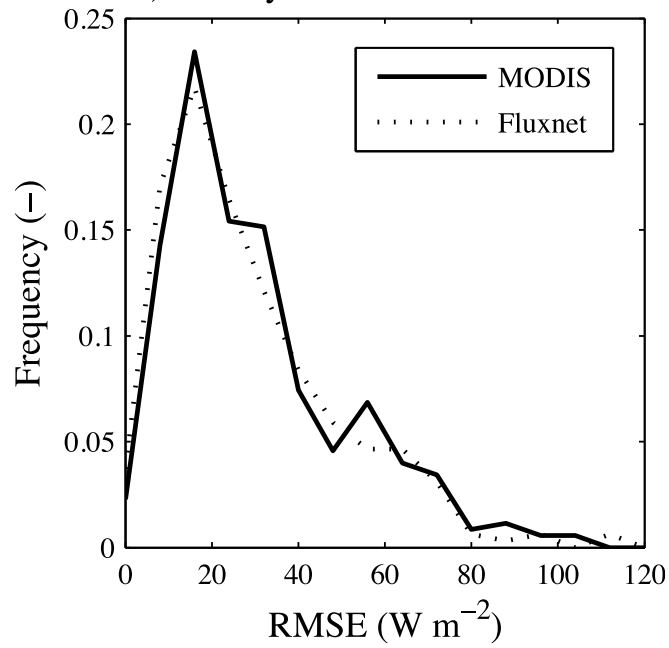

Figure 8. Frequency distribution of RMSE (root mean square error) between eddy covariance and simulated photosynthesis $(G P P)$ and transpiration $(T R)$ for all half-hourly fluxes and average eight-daily fluxes at all sites. The different lines represent the used data: MODIS or Fluxnet.

result of the large deviation in seasonal variation of the parameters for these sites (Figures 6a, 6e, and 6f). Differences between the simulated fluxes are a result of variations in magnitude and seasonality of the ecosystem parameters $V_{c m}$ and $\alpha_{e}$, which are strongly coupled to $L A I$ seasonality.

[33] Results of the half-hourly and average 8-day flux simulations are presented in Figure 8 . For each data set using parameters derived with $L A I_{M}$ or $L A I_{F}$, the distribution of RMSE (root mean square error) is given for simulated against observed GPP and TR fluxes of all sites. The RMSE of simulations using $L A I_{M}$ or $L A I_{F}$ is comparable. Again, there is not a large difference between simulated photosynthesis and transpiration fluxes for the two modeling approaches using MODIS $L A I_{M}$ or Fluxnet $L A I_{F}$.

\section{Discussion}

[34] Model parameters were successfully derived at both the leaf and ecosystem scale for 81 Fluxnet sites. The leaf- scale $v_{c m, 25}$ and $\alpha$ parameters were used to derive seasonal variable ecosystem parameters $V_{c m}$ and $\alpha_{e}$ through explicit upscaling with LAI. In our previous study [Groenendijk et al., 2011] we suggested that the spatial variation of the parameters $v_{c m, 25}$ and $\alpha$ is larger than assumed with PFTs. Here we analyzed the influence of the seasonal parameter variation on PFT parameter variation. From Figure 5 it can be seen that the parameter seasonality is different for PFTs, but there are noticeable patterns. A shorter growing season and a lower maximum $V_{c m, F}$ are seen for the colder sites for all vegetation types. The differences between PFTs are smaller for $\alpha_{e, F}$, the growing season is more similar and the maximum is almost equal. PFT leaf parameters are commonly prescribed in global vegetation schemes as the values in Table 3, which are much more difficult to interpret directly. When comparing this table with the seasonal PFT ecosystem parameters in Figure 5, it is obvious that the leaf parameters explain only a small part of the variation. The variation between PFTs is much easier explained when the 
seasonal meteorological and phenological differences are taken into account.

[35] The two methods in Figure 6 show different seasonality in the ecosystem parameters. This difference is important, as it can lead to an improvement of the seasonal parameters used in global land surface schemes. Variation of the 8-day bulk parameters could be seen as actual parameter values because they are derived directly from the observed data without the use of additional scaling models. Thus when ecosystem parameters deviate from the bulk parameters, this suggests that the scaling assumptions are not correct. But it is also important to keep in mind that the bulk parameters are, at least partly, a response to differences in weather patterns; there is no change in the underlying parameter values. Bulk parameters will therefore likely overestimate the temporal variation. But they appeared to be useful for diagnosing the sites where the model failed to reproduce correct ecosystem parameters, and annual flux simulations were consequently much lower than the observations. The analysis reveals that for grassland and deciduous broadleaf forest sites fluxes cannot be simulated correctly with model parameters only scaled with $L A I$. The seasonal variation of the parameters is larger and has a different pattern. Additional processes related to management and summertime droughts are needed to correctly simulate the fluxes for these sites [Bonal et al., 2008; Wohlfahrt et al., 2008; Churkina et al., 2010; Bellassen et al., 2010]. The phenological LAI submodel is not always able to correctly simulate the seasonal variation of $L A I$ and related ecosystem-scale parameters. This increases the uncertainty of leaf-scale model parameters, which will bias the understanding of the leaf-scale parameter variation.

[36] With tower observations and additional observations of ground-based LAI and leaf-nitrogen content [e.g., Kattge et al., 2009] the parameters can be better constrained for natural vegetation by defining the limits of the different variables responsible for transitions between constraints. Our average leaf-scale $v_{c m, 25 F}$ values (Table 3 ) are within the same ranges as the values derived from a large number of leaf observations [Kattge et al., 2009]. But to be able to relate our leaf-scale parameters to leaf-nitrogen content, observations at the Fluxnet sites are needed. When integrated with meteorological variables to upscale the parameters from the leaf to the ecosystem scale, this approach will be applicable in global models. This is a first step towards a classification with more gradual transitions, comparable to the leaf economics spectrum [Reich et al., 1997; Wright et al., 2004; Harrison et al., 2010].

[37] The seasonal parameter variation in the model is fully assigned to the ecosystem parameters. In the model, leafscale parameters are kept constant for each site, assuming that these parameters are constant during the year. It has been observed that leaf parameters actually vary seasonally in response to environmental conditions. For example $v_{c m, 25}$ of leaves from the upper canopy is lower during periods of drought [Misson et al., 2010] and during the spring recovery phase [Wilson et al., 2001; Monson et al., 2005]. Leaf parameters might not be constant, which could possibly explain why no direct relation between the leaf-scale parameters and average climate is observed. A second explanation might be the relation between photosynthesis and leaf-nitrogen content [Reich et al., 1997; Wright et al., 2004]. Kattge et al. [2009] have shown that variation of $v_{c m, 25}$ is related to a high variability of leaf-nitrogen content, while the variation between PFTs is dominated by photosynthetic nitrogen use efficiency. These relationships with nitrogen content and nitrogen use efficiency could be included in the model definition to constrain $v_{c m, 25}$ and $V_{c m}$. The scale of the studies is different, although Kattge et al. [2009] extrapolated the observations from leaf to globe. On the leaf scale there have been a large number of studies [e.g., Wilson et al., 2001; Medlyn et al., 2002; Xu and Baldocchi, 2003; Mäkelä et al., 2004; Kolari et al., 2007; Misson et al., 2010], yet further work is needed to extrapolate these findings to the ecosystem scale. A combination of eddy-covariance data, leaf observations of nitrogen content, and photosynthetic parameters will be valuable for improving understanding of upscaling from the leaf to the ecosystem and global scale. A third possible explanation is that the model parameters simply are not directly related to meteorological variables because the time needed to adapt to climate is longer than that of the observation time series. This could imply that site-specific parameters are a reflection of the historical environment and vegetation adaptation, which follows more gradual transitions than with static PFTs [Harrison et al., 2010].

[38] At several (predominantly warm and dry) sites a decline of $V_{c m}$ is observed during summer, but it is not reproduced in the seasonal $L A I$ variation. This could be related to the temperature response function, which increases exponentially with temperature. A parabolic function, with a maximum parameter value at a certain temperature and a decline for higher temperatures, as in the work of Farquhar et al. [1980], might be more appropriate, although Thum et al. [2008] and Kattge and Knorr [2007] have suggested otherwise. In the model the relation between photosynthesis and soil water content is controlled by parameter $\beta$ in equation (1); therefore the parameters are assumed to be not sensitive to soil water changes. This can introduce a bias in the sensitivity of the photosynthetic parameters to soil water deficits. More attention should also be paid to the stomatal conductance model formulation, which plays an important role in regulating the amount of transpiration and photosynthesis [Medlyn et al., 2011].

\section{Conclusions}

[39] We presented an approach to derive photosynthetic model parameter variation directly from global Fluxnet eddy-covariance and meteorological data. The variation of the leaf-scale parameters $v_{c m, 25}$ and $\alpha$ was coupled to vegetation type and climate as in a PFT classification. When taking into account the seasonal variation of ecosystem-scale parameters, variation between PFTs is better understood. For example seasonal variation of ecosystem-scale $V_{c m}$ of cold, temperate, and warm evergreen needleleaf forests shows a clear pattern of increasing growing season length and maximum values, while the patterns of leaf-scale parameters between these PFTs are not that obvious.

[40] Seasonal bulk parameters $V_{c m, B}$ and $\alpha_{e, B}$ were derived from eddy-covariance flux observations and used to parameterize a phenological submodel to simulate $L A I_{F}$. The seasonal variation of $L A I_{F}$ was compared with MODIS $L A I_{M}$, with as main difference between the data sets the start of the growing season. The differences between the parameters 
Table A1. Model Parameters and Characteristics of the Fluxnet Sites Used in This Study ${ }^{\mathrm{a}}$

\begin{tabular}{|c|c|c|c|c|c|c|c|c|c|}
\hline Name & Climate & Vegetation & Latitude & Longitude & $n$ & $v_{c m, 25 F}$ & $\alpha_{F}$ & $L A I_{\max }$ & Reference \\
\hline AT-Neu & $\mathrm{TE}$ & GRA & 47.12 & 11.32 & 5 & $47.2(0.5)$ & $0.31(0.02)$ & 6.5 & Wohlfahrt et al. [2008] \\
\hline AU-Fog & $\mathrm{TR}$ & SAV & -12.54 & 131.31 & 2 & $9.3(0.4)$ & $0.06(0.00)$ & $5.1 *$ & - \\
\hline AU-Wac & $\mathrm{TE}$ & $\mathrm{EBF}$ & -37.43 & 145.19 & 3 & $86.0(19.5)$ & $0.56(0.19)$ & $5.5^{*}$ & Wood et al. [2008] \\
\hline BE-Vie & $\mathrm{TE}$ & MFO & 50.31 & 6.00 & 11 & $36.7(0.7)$ & $0.30(0.01)$ & 5.1 & Aubinet et al. [2001] \\
\hline BR-Ban & $\mathrm{TR}$ & EBF & -9.82 & -50.16 & 4 & $38.2(1.3)$ & $0.20(0.01)$ & 5.3 & - \\
\hline BR-Sp1 & TR & SAV & -21.62 & -47.65 & 2 & $93.6(30.3)$ & $0.53(0.13)$ & 4.4 & Santos et al. [2004] \\
\hline $\mathrm{CA}-\mathrm{Ca} 1$ & $\mathrm{TE}$ & ENF & 49.87 & -125.33 & 9 & $54.1(0.2)$ & $0.44(0.00)$ & 8.4 & Humphreys et al. [2006] \\
\hline $\mathrm{CA}-\mathrm{Ca} 2$ & $\mathrm{TE}$ & ENF & 49.87 & -125.29 & 6 & $20.5(0.3)$ & $0.15(0.00)$ & 2.2 & Humphreys et al. [2006] \\
\hline $\mathrm{CA}-\mathrm{Ca} 3$ & $\mathrm{TE}$ & ENF & 49.53 & -124.90 & 5 & $38.8(1.2)$ & $0.18(0.01)$ & 6.7 & Humphreys et al. [2006] \\
\hline CA-Mer & $\mathrm{TC}$ & SAV & 45.41 & -75.52 & 0 & - & - & 1.3 & Lafleur et al. [2003] \\
\hline CA-NS3 & $\mathrm{BO}$ & ENF & 55.91 & -98.38 & 5 & $18.2(1.0)$ & $0.17(0.01)$ & 5.3 & Goulden et al. [2006] \\
\hline CA-NS4 & $\mathrm{BO}$ & ENF & 55.91 & -98.38 & 3 & $8.7(1.4)$ & $0.12(0.03)$ & $4.2 *$ & Goulden et al. [2006] \\
\hline CA-NS5 & $\mathrm{BO}$ & ENF & 55.86 & -98.49 & 5 & $23.8(1.0)$ & $0.21(0.01)$ & 5.5 & Goulden et al. [2006] \\
\hline CA-NS6 & $\mathrm{BO}$ & SAV & 55.92 & -98.96 & 5 & $13.1(0.8)$ & $0.13(0.01)$ & 3.0 & Goulden et al. [2006] \\
\hline CA-Oas & $\mathrm{BO}$ & DBF & 53.63 & -106.20 & 7 & $95.9(4.9)$ & $0.68(0.04)$ & 2.1 & Black et al. [2000] \\
\hline $\mathrm{CA}-\mathrm{Obs}$ & $\mathrm{BO}$ & ENF & 53.99 & -105.12 & 7 & $39.4(0.9)$ & $0.24(0.01)$ & 3.8 & Bergeron et al. [2007] \\
\hline CA-Ojp & $\mathrm{BO}$ & ENF & 53.92 & -104.69 & 7 & $56.0(1.0)$ & $0.42(0.01)$ & 2.6 & Howard et al. [2004] \\
\hline CA-Qcu & $\mathrm{BO}$ & ENF & 49.27 & -74.04 & 6 & $65.7(2.8)$ & $0.64(0.06)$ & 0.8 & Giasson et al. [2006] \\
\hline CA-Qfo & $\mathrm{BO}$ & ENF & 49.69 & -74.34 & 4 & $32.3(2.2)$ & $0.30(0.02)$ & 3.7 & Bergeron et al. [2007] \\
\hline CA-SF1 & $\mathrm{BO}$ & ENF & 54.49 & -105.82 & 3 & $35.9(1.5)$ & $0.32(0.02)$ & 3.4 & Mkhabela et al. [2009] \\
\hline CA-SF2 & $\mathrm{BO}$ & ENF & 54.25 & -105.88 & 3 & $36.9(0.9)$ & $0.34(0.02)$ & 3.0 & Mkhabela et al. [2009] \\
\hline $\mathrm{CA}-\mathrm{SF} 3$ & $\mathrm{BO}$ & ENF & 54.09 & -106.01 & 3 & $38.5(1.3)$ & $0.27(0.00)$ & 1.1 & Mkhabela et al. [2009] \\
\hline CA-SJ1 & $\mathrm{BO}$ & ENF & 53.91 & -104.66 & 5 & $22.2(2.5)$ & $0.30(0.06)$ & 0.8 & Zha et al. [2009] \\
\hline $\mathrm{CA}-\mathrm{SJ} 2$ & $\mathrm{BO}$ & ENF & 53.95 & -104.65 & 3 & $16.6(2.2)$ & $0.19(0.09)$ & 0.5 & Zha et al. [2009] \\
\hline $\mathrm{CA}-\mathrm{SJ} 3$ & $\mathrm{BO}$ & ENF & 53.88 & -104.65 & 2 & $34.8(3.0)$ & $0.23(0.03)$ & 2.9 & Zha et al. $[2009]$ \\
\hline CA-TP4 & $\mathrm{TC}$ & ENF & 42.71 & -80.36 & 3 & $31.0(0.9)$ & $0.24(0.01)$ & 8.0 & Arain and Restrepo-Coupe [2005] \\
\hline $\mathrm{CH}-\mathrm{Oe} 1$ & $\mathrm{TE}$ & GRA & 47.29 & 7.73 & 5 & $55.6(4.0)$ & $0.28(0.02)$ & 4.9 & Ammann et al. [2007] \\
\hline $\mathrm{CN}-\mathrm{HaM}$ & AR & GRA & 37.37 & 101.18 & 3 & $141.6(6.7)$ & $0.56(0.10)$ & 1.1 & Kato et al. [2006] \\
\hline DE-Hai & $\mathrm{TE}$ & $\mathrm{DBF}$ & 51.08 & 10.45 & 7 & $40.1(0.4)$ & $0.25(0.00)$ & 6.1 & Knohl et al. [2003] \\
\hline DE-Kli & TE & CRO & 50.89 & 13.52 & 3 & $107.8(14.6)$ & $0.33(0.11)$ & 9.7 & - \\
\hline DE-Tha & $\mathrm{TE}$ & ENF & 50.96 & 13.57 & 11 & $42.5(0.2)$ & $0.32(0.00)$ & 8.0 & Grünwald and Berhofer [2007] \\
\hline DE-Wet & TE & ENF & 50.45 & 11.46 & 5 & $46.1(2.6)$ & $0.25(0.02)$ & 4.8 & Anthoni et al. [2004] \\
\hline DK-Lva & $\mathrm{TE}$ & GRA & 55.68 & 12.08 & 2 & $77.6(37.0)$ & $0.29(0.09)$ & 6.9 & Gilmanov et al. [2007] \\
\hline DK-Sor & $\mathrm{TE}$ & DBF & 55.49 & 11.65 & 11 & $73.1(0.8)$ & $0.70(0.01)$ & 5.0 & Pilegaard et al. [2003] \\
\hline ES-ES1 & SM & ENF & 39.35 & -0.32 & 8 & $47.7(1.5)$ & $0.33(0.02)$ & 2.6 & Sanz et al. [2004] \\
\hline ES-ES2 & SM & $\mathrm{CRO}$ & 39.28 & -0.32 & 3 & $61.3(1.9)$ & $0.33(0.00)$ & 3.0 & - \\
\hline ES-LMa & SM & SAV & 39.94 & -5.77 & 3 & $49.9(11.0)$ & $0.34(0.05)$ & 2.0 & - \\
\hline ES-VDA & $\mathrm{TE}$ & GRA & 42.15 & 1.45 & 3 & $59.3(3.5)$ & $0.18(0.01)$ & 1.4 & Gilmanov et al. [2007] \\
\hline FI-Hyy & $\mathrm{BO}$ & ENF & 61.85 & 24.29 & 11 & $44.6(0.8)$ & $0.37(0.01)$ & 6.7 & Suni et al. [2003a] \\
\hline FI-Sod & $\mathrm{BO}$ & ENF & 67.36 & 26.64 & 0 & - & - & 1.2 & Suni et al. [2003b] \\
\hline FR-Fon & $\mathrm{TE}$ & DBF & 48.48 & 2.78 & 2 & $81.7(30.5)$ & $0.47(0.19)$ & 5.1 & - \\
\hline FR-LBr & $\mathrm{TE}$ & ENF & 44.72 & -0.77 & 8 & $48.8(0.8)$ & $0.37(0.01)$ & 3.5 & Berbigier et al. [2001] \\
\hline FR-Lq1 & $\mathrm{TE}$ & GRA & 45.64 & 2.74 & 2 & $76.6(3.2)$ & $0.60(0.27)$ & 2.5 & Soussana et al. [2007] \\
\hline FR-Lq2 & $\mathrm{TE}$ & GRA & 45.64 & 2.74 & 1 & $155.1(0.0)$ & $0.65(0.00)$ & 2.3 & Soussana et al. [2007] \\
\hline GF-Guy & $\mathrm{TR}$ & $\mathrm{EBF}$ & 5.28 & -52.93 & 0 & - & - & $5.2 *$ & Bonal et al. [2008] \\
\hline HU-Mat & $\mathrm{TE}$ & GRA & 47.85 & 19.73 & 3 & $33.7(1.9)$ & $0.15(0.01)$ & $3.9 *$ & Pintér et al. [2008] \\
\hline ID-Pag & $\mathrm{TR}$ & EBF & 2.35 & 114.04 & 2 & $46.2(4.9)$ & $0.32(0.02)$ & 5.6 & Hirano et al. [2007] \\
\hline IE-Dri & TE & GRA & 51.99 & -8.75 & 3 & $50.2(2.8)$ & $0.26(0.04)$ & $5.2 *$ & Peichl et al. [2011] \\
\hline IT-Amp & $\mathrm{SM}$ & GRA & 41.90 & 13.61 & 4 & $92.6(7.9)$ & $0.53(0.06)$ & 2.5 & Gilmanov et al. [2007] \\
\hline IT-BCi & SM & $\mathrm{CRO}$ & 40.52 & 14.96 & 3 & $71.9(8.3)$ & $0.34(0.05)$ & 5.8 & Reichstein et al. [2003b] \\
\hline IT-Col & $\mathrm{SM}$ & DBF & 41.85 & 13.59 & 11 & $77.3(0.4)$ & $0.53(0.01)$ & 6.8 & Valentini et al. [1996] \\
\hline IT-Cpz & SM & $\mathrm{EBF}$ & 41.71 & 12.38 & 8 & $30.9(1.3)$ & $0.25(0.01)$ & 3.5 & Garbulksy et al. [2008] \\
\hline IT-Lav & $\mathrm{TE}$ & ENF & 45.96 & 11.28 & 0 & - & - & 8.1 & Marcolla et al. [2003] \\
\hline IT-Lec & SM & $\mathrm{EBF}$ & 43.30 & 11.27 & 2 & $26.9(0.5)$ & $0.23(0.02)$ & 2.5 & Chiesi et al. [2011] \\
\hline IT-LMa & $\mathrm{TE}$ & DBF & 45.58 & 7.15 & 4 & $45.1(2.7)$ & $0.47(0.05)$ & $3.0 *$ & - \\
\hline IT-Mal & $\mathrm{TE}$ & GRA & 46.12 & 11.70 & 4 & $83.6(13.0)$ & $0.33(0.02)$ & 3.9 & Gilmanov et al. [2007] \\
\hline IT-MBo & TE & GRA & 46.02 & 11.05 & 4 & $60.1(2.2)$ & $0.26(0.01)$ & 2.9 & Gianelle et al. [2009] \\
\hline IT-PT1 & SM & $\mathrm{DBF}$ & 45.20 & 9.06 & 0 & - & - & 0.0 & $\hat{\mathrm{E}}-$ \\
\hline IT-Ren & TE & ENF & 46.59 & 11.43 & 8 & $31.6(0.8)$ & $0.15(0.01)$ & 5.1 & Montagnani et al. [2009] \\
\hline IT-Ro1 & $\mathrm{SM}$ & DBF & 42.41 & 11.93 & 7 & $58.4(1.5)$ & $0.40(0.02)$ & 3.0 & Rey et al. [2002] \\
\hline IT-SRo & SM & ENF & 43.73 & 10.28 & 8 & $71.9(2.1)$ & $0.57(0.02)$ & 4.2 & Chiesi et al. [2005] \\
\hline JP-Tom & $\mathrm{TC}$ & MFO & 42.74 & 141.51 & 3 & $80.4(14.4)$ & $0.82(0.09)$ & 9.2 & Hirata et al. [2007] \\
\hline NL-Ca1 & $\mathrm{TE}$ & GRA & 51.97 & 4.93 & 4 & $31.1(1.0)$ & $0.18(0.01)$ & 11.3 & Jacobs et al. [2007] \\
\hline NL-Loo & $\mathrm{TE}$ & ENF & 52.17 & 5.74 & 11 & $50.5(1.0)$ & $0.41(0.01)$ & 2.0 & Dolman et al. [2002] \\
\hline SE-Faj & $\mathrm{TE}$ & GRA & 56.27 & 13.55 & 0 & - & - & 1.0 & Lund et al. [2007] \\
\hline SE-Nor & $\mathrm{TC}$ & ENF & 60.09 & 17.48 & 6 & $50.5(2.4)$ & $0.47(0.03)$ & 4.8 & Lagergren et al. [2008] \\
\hline UK-EBu & TE & GRA & 55.87 & -3.21 & 2 & $48.3(11.9)$ & $0.45(0.14)$ & 3.9 & Soussana et al. [2007] \\
\hline UK-ESa & $\mathrm{TE}$ & $\mathrm{CRO}$ & 55.91 & -2.86 & 3 & $102.6(18.4)$ & $0.40(0.05)$ & $4.7 *$ & - \\
\hline UK-Gri & $\mathrm{TE}$ & ENF & 56.61 & -3.80 & 6 & $52.7(5.3)$ & $0.41(0.01)$ & 7.0 & Rebmann et al. [2005] \\
\hline UK-Ham & $\mathrm{TE}$ & DBF & 51.12 & -0.86 & 0 & - & - & $3.7^{*}$ & - \\
\hline UK-PL3 & $\mathrm{TE}$ & DBF & 51.45 & -1.27 & 1 & $12.1(0.0)$ & $0.12(0.00)$ & $3.9^{*}$ & - \\
\hline US-Bar & $\mathrm{TC}$ & $\mathrm{DBF}$ & 44.06 & -71.29 & 2 & $63.5(30.1)$ & $0.45(0.17)$ & 4.7 & Jenkins et al. [2007] \\
\hline
\end{tabular}


Table A1. (continued)

\begin{tabular}{|c|c|c|c|c|c|c|c|c|c|}
\hline Name & Climate & Vegetation & Latitude & Longitude & $n$ & $v_{c m, 25 F}$ & $\alpha_{F}$ & $L A I_{\max }$ & Reference \\
\hline US-Blo & SM & ENF & 38.90 & -120.63 & 10 & $51.2(0.8)$ & $0.30(0.00)$ & 4.6 & Misson et al. [2005] \\
\hline US-CaV & $\mathrm{TE}$ & GRA & 39.06 & -79.42 & 1 & $33.9(0.0)$ & $0.25(0.00)$ & 3.0 & - \\
\hline US-Dk2 & SM & MFO & 35.97 & -79.10 & 3 & $35.8(1.4)$ & $0.26(0.01)$ & 7.0 & Pataki and Oren [2003] \\
\hline US-Dk3 & SM & MFO & 35.98 & -79.09 & 5 & $43.9(1.5)$ & $0.34(0.01)$ & 5.2 & Pataki and Oren [2003] \\
\hline US-Goo & SM & GRA & 34.25 & -89.97 & 5 & $111.7(7.4)$ & $0.65(0.04)$ & 2.0 & - \\
\hline US-KS2 & SM & SAV & 28.61 & -80.67 & 7 & $38.4(1.5)$ & $0.27(0.01)$ & 2.5 & Powell et al. [2006] \\
\hline US-Me1 & SM & ENF & 44.58 & -121.50 & 2 & $256.8(218.3)$ & $0.43(0.35)$ & $3.1^{*}$ & Irvine et al. [2007] \\
\hline US-Me3 & SM & ENF & 44.32 & -121.61 & 1 & $129.0(0.0)$ & $0.79(0.00)$ & 0.5 & Vickers et al. [2009] \\
\hline US-Me4 & SM & ENF & 44.50 & -121.62 & 0 & - & - & 2.1 & Anthoni et al. [2002] \\
\hline US-MMS & SM & DBF & 39.32 & -86.41 & 0 & - & - & 4.7 & Schmid et al. [2000] \\
\hline US-MOz & SM & $\mathrm{DBF}$ & 38.74 & -92.20 & 1 & $158.0(0.0)$ & $0.82(0.00)$ & 4.2 & Gu et al. [2006] \\
\hline US-NC2 & SM & ENF & 35.80 & -76.67 & 2 & $69.1(1.5)$ & $0.66(0.01)$ & 3.0 & Noormets et al. [2010] \\
\hline US-NR1 & $\mathrm{BO}$ & ENF & 40.03 & -105.55 & 4 & $100.9(11.1)$ & $0.44(0.02)$ & 5.6 & Monson et al. [2002] \\
\hline US-Syv & $\mathrm{TC}$ & MFO & 46.24 & -89.35 & 5 & $29.6(0.8)$ & $0.28(0.01)$ & 7.5 & Desai et al. [2005] \\
\hline US-WCr & $\mathrm{TC}$ & DBF & 45.81 & -90.08 & 8 & $75.2(1.6)$ & $0.53(0.01)$ & 5.4 & Cook et al. [2004] \\
\hline US-Wi4 & $\mathrm{TC}$ & ENF & 46.74 & -91.17 & 4 & $40.9(0.5)$ & $0.38(0.02)$ & 2.8 & Noormets et al. [2007] \\
\hline US-Wrc & SM & ENF & 45.82 & -121.95 & 8 & $71.6(0.8)$ & $0.55(0.01)$ & 9.2 & Falk et al. [2008] \\
\hline VU-Coc & $\mathrm{TR}$ & $\mathrm{EBF}$ & -15.44 & 167.19 & 4 & $44.2(1.2)$ & $0.33(0.01)$ & 5.7 & Roupsard et al. [2006] \\
\hline
\end{tabular}

${ }^{\mathrm{a}}$ The site name codes are a composition of country (first two letters) and site name (last three letters). Vegetation types are cropland (CRO), deciduous broadleaf forest (DBF), evergreen broadleaf forest (EBF), evergreen needleleaf forest (ENF), grassland (GRA), mixed forest (MFO) and savanna (SAV). Climates are arctic (AR), boreal (BO), subtropical Mediterranean (SM), temperate (TE), temperate continental (TC) and tropical (TR). The parameters $v_{c m, 25 F}$ and $\alpha_{F}$ are derived with only Fluxnet tower observations and a tower based $L A I_{\max }$ with $n$ (equal to the number of site years) simulations for each site. An asterisk indicates $L A I_{\max }$ from MODIS.

and fluxes when using $L A I_{F}$ or $L A I_{M}$ were very small, which indicated that the use of Fluxnet and MODIS data sets result in a similar variation of $L A I$. In addition, the seasonal variation of the bulk parameters $V_{c m, B}$ and $\alpha_{e, B}$ was compared with the ecosystem parameters $V_{c m, F}$ and $\alpha_{e, F}$. The main differences were here also seen at the start of the growing season and for the grassland and deciduous forest sites. This indicates that upscaling with both $L A I_{F}$ and $L A I_{M}$ is not sufficient to explain the seasonal variation of $V_{c m}$ and $\alpha_{e}$. Seasonal leaf-scale parameter variations should also be incorporated.

[41] Our hypothesis was that meteorological data could be used to constrain seasonal ecosystem-scale parameter variation. We have shown that this is partly true; the seasonal ecosystem variation is largely explained by the meteorological variation through upscaling with $L A I$. This influence of the seasonal variability on ecosystem-scale parameter variation within a PFT is large and important for our understanding of leaf-scale parameter variation, which can be better separated now. The remaining unexplained variation needs further research and should focus on the relation between seasonal leaf-scale photosynthetic parameters and nitrogen content.

\section{Appendix A: Model Parameters and Characteristics of the Fluxnet Sites Used in This Study}

[42] In Table A1 the model parameters and characteristics of the Fluxnet sites used in this study are presented.

[43] Acknowledgments. The authors gratefully acknowledge the work of all those involved in the collection of the Fluxnet data. Without this global data set this research would not have been possible. This research is funded by a grant from the Netherlands Organization for Scientific Research (NWO) and ICOS-PP. This work used eddy-covariance data acquired by the Fluxnet community and in particular by the following networks: AmeriFlux (U.S. Department of Energy, Biological and Environmental Research, Terrestrial Carbon Program (DE-FG02-04ER63917 and DE-FG02-04ER63911)), AfriFlux, AsiaFlux, CarboAfrica, CarboEuropeIP, CarboItaly, CarboMont, ChinaFlux, Fluxnet-Canada (supported by
CFCAS, NSERC, BIOCAP, Environment Canada, and NRCan), GreenGrass, KoFlux, LBA, NECC, OzFlux, TCOS-Siberia, USCCC. We acknowledge the financial support to the eddy covariance data harmonization provided by CarboEuropeIP, FAO-GTOS-TCO, iLEAPS, Max Planck Institute for Biogeochemistry, National Science Foundation, University of Tuscia, Université Laval and Environment Canada and US Department of Energy and the database development and technical support from Berkeley Water Center, Lawrence Berkeley National Laboratory, Microsoft Research eScience, Oak Ridge National Laboratory, University of California Berkeley, University of Virginia. We acknowledge valuable suggestions from two anonymous reviewers, the associate editor, and Dennis Baldocchi.

\section{References}

Alton, P. B. (2011), How useful are plant functional types in global simulations of the carbon, water, and energy cycles?, J. Geophys. Res., 116, G01030, doi:10.1029/2010JG001430.

Ammann, C., C. Flechard, J. Leifeld, A. Neftel, and J. Fuhrer (2007), The carbon budget of newly established temperate grassland depends on management intensity, Agric. Ecosyst. Environ., 121, 5-20, doi:10.1016/j. agee.2006.12.002

Anthoni, P. M., M. H. Unsworth, B. E. Law, J. Irvine, D. D. Baldocchi, S. Van Tuyl, and D. Moore (2002), Seasonal differences in carbon and water vapor exchange in young and old-growth ponderosa pine ecosystems, Agric. For. Meteorol., 111, 203-222, doi:10.1016/S0168-1923(02) 00021-7.

Anthoni, P. M., A. Knohl, C. Rebmann, A. Freibauer, M. Mund, W. Ziegler, O. Kolle, and E.-D. Schulze (2004), Forest and agricultural land-usedependent $\mathrm{CO}_{2}$ exchange in Thuringia, Germany, Global Change Biol., 10, 2005-2019.

Arain, M. A., and N. Restrepo-Coupe (2005), Net ecosystem production in a temperate pine plantation in southeastern Canada, Agric. For. Meteorol., 128, 223-241, doi:10.1016/j.agrformet.2004.10.003.

Arneth, A., J. Lloyd, H. Šantrůčková, M. Bird, S. Grigoryev, Y. N. Kalaschnikov, G. Gleixner, and E.-D. Schulze (2002), Response of central Siberian Scots pine to soil water deficit and long-term trends in atmospheric $\mathrm{CO}_{2}$ concentration, Global Biogeochem. Cycles, 16(1), 1005, doi:10.1029/2000GB001374.

Arora, V. (2002), Modeling vegetation as a dynamic component in soilvegetation-atmosphere transfer schemes and hydrological models, Rev. Geophys., 40(2), 1006, doi:10.1029/2001RG000103.

Aubinet, M., et al. (2000), Estimates of the annual net carbon and water exchange of forests: The EUROFLUX methodology, Adv. Ecol. Res., 30, 113-175.

Aubinet, M., B. Chermanne, M. Vandenhaute, B. Longdoz, M. Yernaux, and E. Laitat (2001), Long term carbon dioxide exchange above a mixed forest in the Belgian Ardennes, Agric. For. Meteorol., 108, 293-315. 
Baldocchi, D. (2008), Turner Review No. 15. "Breathing" of the terrestrial biosphere: Lessons learned from a global network of carbon dioxide flux measurement systems, Aust. J. Bot., 56, 1-26, doi:10.1071/BT07151.

Baldocchi, D. D., and P. C. Harley (1995), Scaling carbon dioxide and water vapour exchange from leaf to canopy in a deciduous forest. II Model testing and application, Plant Cell Environ., 18, 1157-1173.

Baldocchi, D., et al. (2001), Fluxnet: A new tool to study the temporal and spatial variability of ecosystem-scale carbon dioxide, water vapor, and energy flux densities, Bull. Am. Meteorol. Soc., 82(11), 2415-2434, doi:10.1175/1520-0477(2001)082<2415:FANTTS $>2.3 . C O ; 2$

Bellassen, V., G. Le Mair, J. F. Dhôte, P. Ciais, and N. Viovy (2010), Modelling forest management within a global vegetation model-Part 1 : Model structure and general behaviour, Ecol. Modell., 221, 2458-2474.

Berbigier, P., J.-M. Bonnefond, and P. Mellmann (2001), $\mathrm{CO}_{2}$ and water vapour fluxes for 2 years above Euroflux forest site, Agric. For. Meteorol., 108, 183-197, doi:10.1016/S0168-1923(01)00240-4.

Bergeron, O., H. A. Margolis, T. A. Black, C. Coursolle, A. L. Dunn, A. G. Barr, and S. C. Wofsy (2007), Comparison of carbon dioxide fluxes over three boreal black spruce forests in Canada, Global Change Biol., 13, 89-107, doi:10.1111/j.1365-2486.2006.01281.x.

Black, T. A., W. J. Chen, and A. G. Barr (2000), Increased carbon sequestration by a boreal deciduous forest in years with a warm spring, Geophys. Res. Lett., 27, 1271-1274.

Bonal, D., et al. (2008), Impact of severe dry season on net ecosystem exchange in the Neotropical rainforest of French Guiana, Global Change Biol., 14, 1917-1933, doi:10.1111/j.1365-2486.2008.01610.x.

Bonan, G. B., S. Levin, L. Kergoat, and K. W. Oleson (2002), Landscapes as patches of plant functional types: An integrating concept for climate and ecosystem models, Global Biogeochem. Cycles, 16(2), 1021, doi:10.1029/2000GB001360.

Bonan, G. B., S. Levis, S. Sitch, M. Vertenstein, and K. W. Oleson (2003), A dynamic global vegetation model for use with climate models: Concepts and description of simulated vegetation dynamics, Global Change Biol., 9, 1543-1566.

Box, E. O. (1996), Plant functional types and climate at the global scale, J. Veg. Sci., 7, 309-320.

Chiesi, M., F. Maselli, M. Bindi, L. Fibbi, P. Cherubina, E. Arlotta G. Tirone, G. Matteucci, and G. Seufert (2005), Modelling carbon budget of Mediterranean forests using ground and remote sensing measurements, Agric. For. Meteorol., 135, 22-34, doi:10.1016/j.agrformet.2005.09.011.

Chiesi, M., L. Fibbi, L. Genesio, B. Gioli, R. Magno, F. Maselli, M. Moriondo, and F. P. Vaccari (2011), Integration of ground and satellite data to model Mediterranean forest processes, Int. J. Appl. Earth Observ. Geoinf., 13, 504-515.

Churkina, G., et al. (2010), Interactions between nitrogen deposition, land cover conversion, and climate change determine the contemporary carbon balance of Europe, Biogeosciences, 7, 2749-2764.

Cook, B. D., et al. (2004), Carbon exchange and venting anomalies in an upland deciduous forest in northern Wisconsin, USA, Agric. For. Meteorol., 126, 271-295, doi:10.1016/j.agrformet.2004.06.008.

Cowan, I. R. (1977), Stomatal behaviour and environment, Adv. Bot. Res. 4, 117-228.

Cox, P. M., C. Huntingford, and R. J. Harding (1998), A canopy conductance and photosynthesis model for use in a GCM land surface scheme J. Hydrol., 212-213, 79-94.

Dauzat, J., B. Rapidel, and A. Berger (2001), Simulation of leaf transpiration and sap flow in virtual plants: Model description and application to a coffee plantation in Costa Rica, Agric. For. Meteorol., 109, 143-160.

de Pury, D. G. G., and G. D. Farquhar (1997), Simple scaling of photosynthesis from leaves to canopies without the errors of big-leaf models, Plant Cell Environ., 20, 537-557.

Desai, A. R., P. V. Bolstad, B. D. Cook, K. J. Davis, and E. V. Carey (2005), Comparing net ecosystem exchange of carbon dioxide between an old-growth and mature forest in the upper Midwest, USA, Agric. For. Meteorol., 128, 33-55, doi:10.1016/j.agrformet.2004.09.005.

Distributed Active Archive Center (2009), MODIS subsetted land products, Collection 5, Oak Ridge Natl. Lab., Oak Ridge, Tenn. [Available at http://www.daac.ornl.gov/MODIS/modis.html.]

Dolman, A. J., E. J. Moors, and J. A. Elbers (2002), The carbon uptake of a mid latitude forest on sandy soil, Agric. For. Meteorol., 111, 157-170.

Falk, M., S. Wharton, M. Schroeder, S. Ustin, and K. T. Paw U (2008), Flux partitioning in an old-growth forest: Seasonal and interannual dynamics, Tree Physiol., 28, 509-520.

Farquhar, G. D., S. von Caemmerer, and J. A. Berry (1980), A biochemical model of photosynthetic $\mathrm{CO}_{2}$ assimilation in leaves of $\mathrm{C}_{3}$ species, Planta, 149, 78-90.

Field, C. (1983), Allocating leaf nitrogen for the maximization of carbon gain: Leaf age as a control on the allocation program, Oecologia, 56, $341-347$.
Foley, J. A., S. Levis, I. C. Prentice, D. Pollard, and S. L. Thompson (1998), Coupling dynamic models of climate and vegetation, Global Change Biol., 4, 561-579, doi:10.1046/j.1365-2486.1998.t01-1-00168.x. Garbulksy, M. F., J. Peñuelas, D. Papale, and I. Fillela (2008), Remote estimation of carbon dioxide uptake by a Mediterranean forest, Global Change Biol., 14, 2860-2867, doi:10.1111/j.1365-2486.2008.01684.x.

Gianelle, D., L. Vescovo, B. Marcolla, G. Manca, and A. Cescatti (2009), Ecosystem carbon fluxes and canopy spectral reflectance of a mountain meadow, Int. J. Remote Sens., 30(2), 435-449, doi:10.1080/ 01431160802314855

Giasson, M.-A., C. Coursolle, and H. A. Margolis (2006), Ecosystem-level $\mathrm{CO}_{2}$ fluxes from a boreal cutover in eastern Canada before and after scarification, Agric. For. Meteorol., 140, 23-40, doi:10.1016/j.agrformet. 2006.08.001.

Gilmanov, T. G., et al. (2007), Partitioning European grassland net ecosystem $\mathrm{CO}_{2}$ exchange into gross primary productivity and ecosystem respiration using light response function analysis, Agric. Ecosyst. Environ. 121, 93-120, doi:10.1016/j.agee.2006.12.008.

Goulden, M. L., G. C. Winston, A. M. S. McMillan, M. E. Litvak, E. L. Read, A. V. Rocha, and J. R. Elliot (2006), An eddy covariance mesonet to measure the effect of forest age on land-atmosphere exchange, Global Change Biol., 12, 2146-2162, doi:10.1111/j.1365-2486.2006.01251.x.

Groenendijk, M., et al. (2011), Assessing parameter variability in a photosynthesis model within and between plant functional types using global Fluxnet eddy covariance data, Agric. For. Meteorol., 151, 22-38, doi:10.1016/j.agrformet.2010.08.013.

Grünwald, T., and C. Berhofer (2007), A decade of carbon, water and energy flux measurements of an old spruce forest at the Anchor Station Tharandt, Tellus, Ser. B, 59, 387-396, doi:10.1111/j.1600-0889.2007. 00259.x.

Gu, L., et al. (2006), Direct and indirect effects of atmospheric conditions and soil moisture on surface energy partitioning revealed by a prolonged drought at a temperate forest site, J. Geophys. Res., 111, D16102, doi:10.1029/2006JD007161.

Harrison, S. P., I. C. Prentice, D. Barboni, K. E. Kohfeld, J. Ni, and J.-P. Sutra (2010), Ecophysiological and bioclimatic foundations for a global plant functional classification, J. Veg. Sci., 21, 300-317, doi:10.1111/ j.1654-1103.2009.01144.x.

Hirano, T. H., H. Segah, T. Harada, S. Limin, T. June, R. Hirata, and M. Osaki (2007), Carbon dioxide balance of a tropical peat swamp fores in Kalimantan, Indonesia, Global Change Biol., 13, 412-425, doi:10.1111/j.1365-2486.2006.01301.x.

Hirata, R., T. Hirano, N. Saigusa, Y. Fujinuma, K. Inukai, Y. Kitamori, Y. Takahashi, and S. Yamamoto (2007), Seasonal and interannual variations in carbon dioxide exchange of a temperate larch forest, Agric. For. Meteorol., 147, 110-124, doi:10.1016/j.agrformet.2007.07.005.

Howard, E. A., S. T. Gower, J. A. Foley, and C. J. Kucharik (2004), Effects of logging on carbon dynamics of a jack pine forest in Saskatchewan, Canada, Global Change Biol., 10, 1267-1284.

Humphreys, E. R., T. A. Black, K. Morgenstern, T. Cai, G. B. Drewitt, Z. Nesic, and J. A. Trofymow (2006), Carbon dioxide fluxes in coastal Douglas-fir stands at different stages of development after clearcut harvesting, Agric. For. Meteorol., 140, 6-22, doi:10.1016/j.agrformet. 2006.03.018.

Irvine, J., B. E. Law, and K. A. Hibbard (2007), Postfire carbon pools and fluxes in semiarid ponderosa pine in central Oregon, Global Change Biol., 13, 1748-1760, doi:10.1111/j.1365-2486.2007.01368.x.

Jacobs, C. M. J., et al. (2007), Variability of annual $\mathrm{CO}_{2}$ exchange from Dutch grasslands, Biogeosciences, 4, 803-816.

Jarvis, P. G. (1995), Scaling processes and problems, Plant Cell Environ., $18,1079-1089$

Jenkins, J. P., A. D. Richardson, B. H. Braswell, S. V. Ollinger, D. Y. Hollinger, and M.-L. Smith (2007), Refining light-use efficiency calculations for a deciduous forest canopy using simultaneous tower-based carbon flux and radiometric measurements, Agric. For. Meteorol., 143, 64-79, doi:10.1016/j.agrformet.2006.11.008.

Jolly, W. M., R. Nemani, and S. W. Running (2005), A generalized, bioclimatic index to predict foliar phenology in response to climate, Global Change Biol., 11, 619-632, doi:10.1111/j.1365-2486.2005.00930.x.

Kato, T., Y. Tang, M. Gu, S. Hirota, M. Du, Y. Li, and X. Zhao (2006), Temperature and biomass influences on interannual changes in $\mathrm{CO}_{2}$ exchange in an alpine meadow on the Qinghai-Tibetan Plateau, Global Change Biol., 12, 1285-1298, doi:10.1111/j.1365-2486.2006.01153.x.

Kattge, J., and W. Knorr (2007), Temperature acclimation in a biochemical model of photosynthesis: A reanalysis of data from 36 species, Plant Cell Environ., 30, 1176-1190, doi:10.1111/j.1365-3040.2007.01690.x.

Kattge, J., W. Knorr, T. Raddatz, and C. Wirth (2009), Quantifying photosynthetic capacity and its relationship to leaf nitrogen content for 
global-scale terrestrial biosphere models, Global Change Biol., 15 976-991, doi:10.1111/j.1365-2486.2008.01744.x.

Knohl, A., E.-D. Schulze, O. Kolle, and N. Buchmann (2003), Large carbon uptake by an unmanaged 250-year-old deciduous forest in central Germany, Agric. For. Meteorol., 118, 151-167, doi:10.1016/S0168-1923 (03)00115-1.

Knorr, W. (2000), Annual and interannual $\mathrm{CO}_{2}$ exchanges of the terrestrial biosphere: Process-based simulations and uncertainties, Global Ecol. Biogeogr., 9, 225-252.

Knorr, W., and J. Kattge (2005), Inversion of terrestrial ecosystem model parameter values against eddy covariance measurements by Monte Carlo sampling, Global Change Biol., 11, 1333-1351.

Kolari, P., H. K. Lappalainen, H. Hänninen, and P. Hari (2007), Relationship between temperature and the seasonal course of photosynthesis in Scots pine at northern timberline and in southern boreal zone, Tellus, Ser. B, 59, 542-552, doi:10.1111/j.1600-0889.2007.00262.x.

Krinner, G., N. Viovy, N. de Noblet-Ducoudré, J. Ogée, J. Polcher, P. Friedlingstein, P. Ciais, S. Sitch, and I. C. Prentice (2005), A dynamic global vegetation model for studies of the coupled atmosphere-biosphere system, Global Biogeochem. Cycles, 19, GB1015, doi:10.1029/ 2003GB002199.

Kull, O., and P. G. Jarvis (1995), The role of nitrogen in a simple scheme to scale up photosynthesis from leaf to canopy, Plant Cell Environ., 18, 1174-1182.

Lafleur, P. M., N. T. Roulet, J. L. Bubier, S. Frolking, and T. R. Moore (2003), Interannual variability in the peatland-atmosphere carbon dioxide exchange at an ombrotrophic bog, Global Biogeochem. Cycles, 17(2), 1036, doi:10.1029/2002GB001983.

Lagarias, J. C., J. A. Reeds, M. H. Wright, and P. E. Wright (1998), Convergence properties of the Nelder-Mead simplex method in low dimensions, SIAM J. Optim., 9(1), 122-147.

Lagergren, F., et al. (2008), Biophysical controls on $\mathrm{CO}_{2}$ fluxes of three northern forests based on long-term eddy covariance data, Tellus, Ser. $B, 60,143-152$, doi:10.1111/j.1600-0889.2006.00324.x.

Lasslop, G., M. Reichstein, J. Kattge, and D. Papale (2008), Influences of observation errors in eddy flux data on inverse model parameter estimation, Biogeosciences, 5, 1311-1324.

Lasslop, G., M. Reichstein, M. Detto, A. D. Richardson, and D. D. Baldocch (2010), Comment on Vickers et al.: Self-correlation between assimilation and respiration resulting from flux partitioning of eddy-covariance $\mathrm{CO}_{2}$ fluxes, Agric. For. Meteorol., 150, 312-314.

Law, B. E., and R. H. Waring (1994), Remote sensing of leaf area index and radiation intercepted by understory vegetation, Ecol. Appl., 42(2), 272-279.

Leuning, R. (2002), Temperature dependence of two parameters in a photosynthesis model, Plant Cell Environ., 25, 1205-1210, doi:10.1046/ j.1365-3040.2002.00898.x.

Lindroth, A., et al. (2008), Leaf area index is the principal scaling parameter for both gross photosynthesis and ecosystem respiration of northern deciduous and coniferous forests, Tellus, Ser. B, 60, 129-142, doi: $10.1111 /$ j.1600-0889.2007.00330.x.

Lund, M., A. Lindroth, and T. Christensen (2007), Annual $\mathrm{CO}_{2}$ balance of a temperate bog, Tellus, Ser. B, 59, 804-811, doi:10.1111/j.1600-0889. 2007.00303.x.

Mäkelä, A., P. Hari, F. Berninger, H. Hänninen, and E. Nikinmaa (2004), Acclimation of photosynthetic capacity in Scots pine to the annual cycle of temperature, Tree Physiol., 24, 369-376.

Marcolla, B., A. Pitacco, and A. Cescatti (2003), Canopy architecture and turbulence structure in a coniferous forest, Boundary Layer Meteorol. 108, 39-59.

Medlyn, B. E., D. Loustau, and S. Delzon (2002), Temperature response of parameters of a biochemically based model of photosynthesis. I. Seasonal changes in mature maritime pine (Pinus pinaster Ait.), Plant Cell Environ., 25, 1155-1165.

Medlyn, B. E., et al. (2005), Carbon balance of coniferous forests growing in contrasting climates: Model-based analysis, Agric. For. Meteorol., $131,97-124$.

Medlyn, B. E., et al. (2011), Reconciling the optimal and empirica approaches to modelling stomatal conductance, Global Change Biol., 17, 2134-2144.

Misson, L., J. Tang, M. Xu, M. McKay, and A. Goldstein (2005), Influences of recovery from clear-cut, climate variability, and thinning on the carbon balance of a young ponderosa pine plantation, Agric. For. Meteorol., 130, 207-222, doi:10.1016/j.agrformet.2005.04.001.

Misson, L., K. P. Tu, R. A. Boniello, and A. H. Goldstein (2006), Seasonality of photosynthetic parameters in a multi-specific and vertically complex forest ecosystem in the Sierra Nevada of California, Tree Physiol., 26, 729-741.
Misson, L., J.-M. Limousin, R. Rodrigues, and M. G. Letts (2010), Leaf physiological responses to extreme droughts in Mediterranean Quercus ilex forest, Plant Cell Environ., 33, 1898-1910, doi:10.1111/j.13653040.2010.02193.x.

Mkhabela, M. S., et al. (2009), Comparison of carbon dynamics and water use efficiency following fire and harvesting in Canadian boreal forests, Agric. For. Meteorol., 149, 783-794, doi:10.1016/j.agrformet.2008. 10.025 .

Mo, X., J. M. Chen, W. Ju, and T. A. Black (2008), Optimization of ecosystem model parameters through assimilating eddy covariance flux data with an ensemble Kalman filter, Ecol. Modell., 217, 157-173.

Moffat, A. M., et al. (2007), Comprehensive comparison of gap-filling techniques for eddy covariance net carbon fluxes, Agric. For. Meteorol. 147, 209-232, doi:10.1016/j.agrformet.2007.08.011.

Monson, R. K., A. A. Turnipseed, J. P. Sparks, P. C. Harley, L. E. ScottDenton, K. Sparks, and T. E. Huxman (2002), Carbon sequestration in a high-elevation, subalpine forest, Global Change Biol., 8, 459-478, doi:10.1046/j.1365-2486.2002.00480.x.

Monson, R. K., et al. (2005), Climatic influences on net ecosystem $\mathrm{CO}_{2}$ exchange during the transition from wintertime carbon source to springtime carbon sink in a high-elevation, subalpine forest, Oecologia, 146, $130-147$.

Montagnani, L., et al. (2009), A new mass conservation approach to the study of $\mathrm{CO}_{2}$ advection in an alpine forest, J. Geophys. Res., 114, D07306, doi:10.1029/2008JD010650.

Noormets, A., J. Chen, and T. R. Crow (2007), Age-dependent changes in ecosystem carbon fluxes in managed forests in northern Wisconsin, USA Ecosystems, 10, 187-203, doi:10.1007/s10021-007-9018-y.

Noormets, A., M. J. Gavazzi, S. G. McNulty, J.-C. Domec, G. Sun, J. S. King, and J. Chen (2010), Response of carbon fluxes to drought in a coastal plain loblolly pine forest, Global Change Biol., 16, 272-287, doi:10.1111/j.1365-2486.2009.01928.x.

Owen, K. E., et al. (2007), Linking flux network measurements to continental scale simulations: Ecosystem carbon dioxide exchange capacity under non-water-stressed conditions, Global Change Biol., 13, 1-27, doi:10.1111/j.1365-2486.2006.01326.x.

Papale, D., and R. Valentini (2003), A new assessment of European forests carbon exchanges by eddy fluxes and artificial neural network spatialization, Global Change Biol., 9, 525-535

Papale, D., et al. (2006), Towards a standardized processing of net ecosystem exchange measured with eddy covariance technique: Algorithms and uncertainty estimation, Biogeosciences, 3, 571-583.

Pataki, D. E., and R. Oren (2003), Species differences in stomatal control of water loss at the canopy scale in a mature bottomland deciduous forest, Adv. Water Resour., 26, 1267-1278, doi:10.1016/j.advwatres.2003. 08.001 .

Peichl, M., P. Leahy, and G. Kiely (2011), Six-year stable annual uptake of carbon dioxide in intensively managed humid temperate grassland, Ecosystems, 14, 112-126.

Pilegaard, K., T. N. Mikkelsen, C. Beier, N. O. Jensen, P. Ambus, and H. Ro-Poulsen (2003), Field measurements of atmosphere-biosphere interactions in a Danish beech forest, Bor. Environ. Res., 8, 315-333.

Pintér, K., Z. Barcza, J. Balogh, S. Czóbel, Z. Csintalan, Z. Tuba, and Z. Nagy (2008), Interannual variability of grasslands' carbon balance depends on soil type, Comm. Ecol., 9, 43-48, doi:10.1556/ComEc. 9.2008.S.7.

Powell, T. L., R. Bracho, J. Li, S. Dore, C. R. Hinkle, and B. G. Drake (2006), Environmental controls over net ecosystem carbon exchange of scrub oak in central Florida, Agric. For. Meteorol., 141, 19-34, doi:10.1016/j.agrformet.2006.09.002.

Rebmann, C., et al. (2005), Quality analysis applied on eddy covariance measurements at complex forest sites using footprint modelling, Theor. Appl. Climatol, 80, 121-141, doi:10.1007/s00704-004-0095-y.

Reich, P. B., M. B. Walters, and D. S. Ellsworth (1997), From tropics to tundra: Global convergence in plant functioning, Proc. Natl. Acad. Sci. U.S.A., 94, 13,730-13,734.

Reichstein, M., et al. (2003a), Inverse modeling of seasonal drought effects on canopy $\mathrm{CO}_{2} / \mathrm{H}_{2} \mathrm{O}$ exchange in three Mediterranean ecosystems, J. Geophys. Res., 108(23), 4726, doi:10.1029/2003JD003430.

Reichstein, M., et al. (2003b), Modeling temporal and large-scale spatial variability of soil respiration from soil water availability, temperature and vegetation productivity indices, Global Biogeochem. Cycles, 17(4), 1104, doi:10.1029/2003GB002035.

Reichstein, M., et al. (2005), On the separation of net ecosystem exchange into assimilation and ecosystem respiration: Review and improved algorithm, Global Change Biol., 11, 1424-1439, doi:10.1111/j.1365-2486. 2005.001002.x.

Rey, A., E. Pegoraro, V. Tedeschi, I. De Parri, P. G. Jarvis, and R. Valentini (2002), Annual variation in soil respiration and its components in a 
coppice oak forest in central Italy, Global Change Biol., 8, 851-866, doi:10.1046/j.1365-2486.2002.00521.x.

Roupsard, O., et al. (2006), Partitioning energy and evapo-transpiration above and below a tropical palm canopy, Agric. For. Meteorol., 139, 252-268, doi:10.1016/j.agrformet.2006.07.006.

Santos, A. J. B., C. A. Quesada, G. T. Da Silva, J. F. Maia, H. S. Miranda, A. C. Miranda, and J. Lloyd (2004), High rates of net ecosystem carbon assimilation by Brachiara pasture in the Brazilian Cerrado, Global Change Biol., 10, 877-885, doi:10.1111/j.1529-8817.2003.00777.x.

Sanz, M. J., A. Carrara, and C. Gimeno (2004), Effects of a dry and warm summer conditions on $\mathrm{CO}_{2}$ and energy fluxes from three Mediterranean ecosystems, Geophys. Res. Abstr., 6, 3239.

Schmid, H. P., C. S. B. Grimmond, F. Cropley, B. Offerle, and H.-B. Su (2000), Measurements of $\mathrm{CO}_{2}$ and energy fluxes over a mixed hardwood forest in the mid-western United States, Agric. For. Meteorol., 103, 357-374, doi:10.1016/S0168-1923(00)00140-4.

Sellers, P. J., J. A. Berry, G. J. Collatz, C. B. Field, and F. G. Hall (1992), Canopy reflectance, photosynthesis and transpiration. III. A reanalysis using improved leaf models and a new canopy integration scheme, Remote Sens. Environ., 42, 187-216.

Sellers, P. J., et al. (1997), Modeling the exchanges of energy, water, and carbon between continents and the atmosphere, Science, 275, 502-509.

Sitch, S., et al. (2003), Evaluation of ecosystem dynamics, plant geography and terrestrial carbon cycling in the LPJ dynamic global vegetation model, Global Change Biol., 9, 161-185.

Soussana, J. F., et al. (2007), Full accounting of the greenhouse gas $\left(\mathrm{CO}_{2}\right.$, $\mathrm{N}_{2} \mathrm{O}, \mathrm{CH}_{4}$ ) budget of nine European grassland sites, Agric. Ecosyst. Environ., 121, 121-134.

Stöckli, R., T. Ruttishauer, D. Dragoni, J. O'Keefe, P. E. Thornton, M. Jolly, L. Lu, and A. S. Denning (2008), Remote sensing data assimilation for a prognostic phenology model, J. Geophys. Res., 113, G04021, doi:10.1029/2008JG000781.

Suni, T., et al. (2003a), Air temperature triggers the recovery of evergreen boreal forest photosynthesis in spring, Global Change Biol., 9 , $1410-1426$.

Suni, T., J. Rinne, A. Reissell, N. Altimir, P. Keronen, Ü. Rannik, M. D. Maso, M. Kulmala, and T. Vesala (2003b), Long-term measurements of surface fluxes above a Scots pine forest in Hyytiälä, southern Finland, 1996-2001, Bor. Environ. Res., 8, 287-301.

Thum, T., T. Aalto, T. Laurila, M. Aurela, A. Lindroth, and T. Vesala (2008), Assessing seasonality of biochemical $\mathrm{CO}_{2}$ exchange model parameters from micrometeorological flux observations at boreal coniferous forest, Biogeosciences, 5, 1625-1639.

Valentini, R., P. D. Angelis, G. Matteuci, R. Monaco, S. Dore, and G. E. Scarascia Mucnozza (1996), Seasonal net carbon dioxide exchange of a beech forest with the atmosphere, Global Change Biol., 2, 199-207, doi:10.1111/j.1365-2486.1996.tb00072.x.

Vickers, D., C. Thomas, and B. E. Law (2009), Random and systematic $\mathrm{CO}_{2}$ flux sampling errors for tower measurements over forests in the convective boundary layer, Agric. For. Meteorol., 149, 73-83, doi:10.1016/j. agrformet.2008.07.005.

Wang, Q., J. Tenhunen, E. Falge, C. Bernhofer, A. Granier, and T. Vesala (2003), Simulation and scaling of temporal variations in gross primary production for coniferous and deciduous temperate forests, Global Change Biol., 10, 37-51.

Wang, Y. P., D. Baldocchi, R. Leuning, E. Falge, and T. Vesala (2007), Estimating parameters in a land-surface model by applying nonlinear inversion to eddy covariance flux measurements from eight Fluxnet sites, Global Change Biol., 12, 1-19.

Williams, M., et al. (2009), Improving land surface models with Fluxnet data, Biogeosciences, 6, 1341-1359.

Wilson, K. B., D. D. Baldocchi, and P. J. Hanson (2001), Leaf age affects the seasonal pattern of photosynthetic capacity and net ecosystem exchange of carbon in a deciduous forest, Plant Cell Environ., 24, 571-583.

Wohlfahrt, G., A. Hammerle, A. Haslwanter, M. Bahn, U. Tappeiner, and A. Cernusca (2008), Seasonal and inter-annual variability of the net ecosystem $\mathrm{CO}_{2}$ exchange of a temperate mountain grassland: Effects of weather and management, J. Geophys. Res., 113, D08110, doi:10.1029/2007JD009286.

Wolf, A., K. Ashalov, N. Saliendra, D. A. Johnson, and E. A. Laca (2006), Inverse estimation of $\mathrm{Vc}_{\max }$, leaf area index, and the Ball-Berry parameter from carbon and energy fluxes, J. Geophys. Res., 111, D08S08, doi:10.1029/2005JD005927.

Wood, S. A., J. Beringer, L. B. Hutley, A. D. McGuire, A. J. van Dijk, and M. Kilinc (2008), Impacts of fire on forest age and runoff in mountain ash forests, Funct. Plant Biol., 35, 483-492, doi:10.1071/FP08120.

Wright, I. J., et al. (2004), The worldwide leaf economics spectrum, Nature, 428, 821-827.

Wullschleger, S. D. (1993), Biochemical limitations of carbon assimilation in c c plants - A retrospective analysis of the a/c i curves from 109 species, J. Exp. Bot., 44(262), 907-920.

$\mathrm{Xu}$, L., and D. D. Baldocchi (2003), Seasonal trends in photosynthetic parameters and stomatal conductance of blue oak (Quercus douglasii) under prolonged summer drought and high temperature, Tree Physiol., $23,865-877$.

Zha, T., et al. (2009), Carbon sequestration in boreal jack pine stands following harvesting, Global Change Biol., 15, 1475-1487, doi:10.1111/ j.1365-2486.2008.01817.x.

C. Ammann, Federal Research Station Agroscope ART, Reckenholzstr. 191, CH-8046 Zürich, Switzerland.

A. Arneth and M. Lund, Department of Earth and Ecosystem Sciences, Division of Physical Geography and Ecosystem Analysis, Lund University, Sölvegatan 12, SE-22362 Lund, Sweden.

A. Cescatti, European Commission, Joint Research Centre, Institute for Environment and Sustainability, Via E. Fermi 2749, I-21027 Ispra, Italy.

A. J. Dolman and J. H. C. Gash, Department of Hydrology and GeoEnvironmental Sciences, Faculty of Earth and Life Sciences, VU University Amsterdam, De Boelelaan 1085, NL-1081 HV Amsterdam, Netherlands.

D. Dragoni, Department of Geography, Indiana University, MSBII, No. 310, 702 North Walnut Grove, Bloomington, IN 47405, USA.

D. Gianelle and B. Marcolla, Sustainable Agro-ecosystems and Bioresources Department, IASMA Research and Innovation Centre, Fondazione Edmund Mach, Via E. Mach 1, I-38010 San Michele all'Adige, Italy.

B. Gioli, Institute of Biometeorology, CNR, Via G. Caproni 8, I-50145 Firenze, Italy.

M. Groenendijk, College of Engineering, Mathematics and Physical Sciences, University of Exeter, Exeter EX4 4QF, UK. (m.groenendijk@) exeter.ac.uk)

G. Kiely, Hydromet Research Group, Civil and Environmental Engineering Department, University College Cork, College Road, Cork, Ireland.

A. Knohl, Department of Bioclimatology, Büsgen Institute, GeorgAugust University of Göttingen, Büsgenweg 2, D-37077 Göttingen, Germany.

B. E. Law, College of Forestry, Oregon State University, 328 Richardson Hall, Corvallis, OR 97331, USA.

L. Montagnani, Forest Services and Agency for the Environment, I-39100 Bolzano, Italy.

E. Moors, Earth System Science and Climate Change Group, Alterra, Wageningen University and Research Centre, NL-6700 AA Wageningen, Netherlands.

A. D. Richardson, Department of Organismic and Evolutionary Biology, Harvard University, 22 Divinity Ave., Cambridge, MA 02138, USA.

O. Roupsard, UMR Eco and Sols, French Agricultural Research Centre for International Development, F-34060 Montpellier, France.

M. K. van der Molen, Meteorology and Air Quality Group, Wageningen University and Research Centre, NL-6700 AA Wageningen, Netherlands.

H. Verbeeck, Laboratory of Plant Ecology, Ghent University, Coupure Links 653, B-9000 Ghent, Belgium.

G. Wohlfahrt, Institut für Ökologie, Universität Innsbruck, Sternwartestr. 15, A-6020 Innsbruck, Austria. 